\title{
Systemic inflammatory status predict the outcome of k-RAS WT metastatic colorectal cancer patients receiving the thymidylate synthase poly-epitope-peptide anticancer vaccine
}

\author{
Pierpaolo Correale ${ }^{1}$, Cirino Botta ${ }^{2}$, Nicoletta Staropoli ${ }^{3}$, Valerio Nardone ${ }^{4}$, Pierpaolo \\ Pastina $^{4}$, Cristina Ulivieri ${ }^{5}$, Claudia Gandolfo ${ }^{6}$, Tatiana Cosima Baldari ${ }^{5}$, Stefano \\ Lazzi7, Domenico Ciliberto $^{3}$, Rocco Giannicola ${ }^{1}$, Antonella Fioravanti ${ }^{8}$, Antonio \\ Giordano, Silvia Zappavigna ${ }^{10}$, Michele Caraglia9,10, Pierfrancesco Tassone $^{2,3,10}$, \\ Luigi Pirtoli ${ }^{4}$, Maria Grazia Cusi ${ }^{6}$ and Pierosandro Tagliaferri ${ }^{3}$

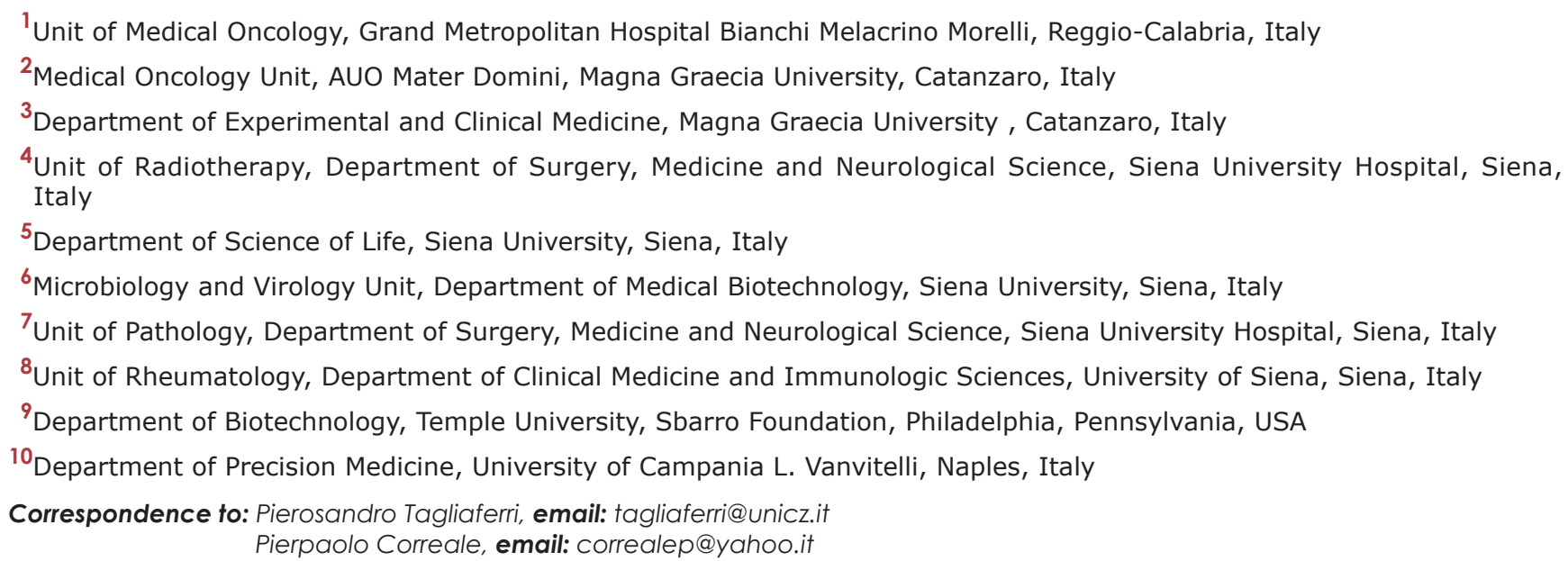

Keywords: bio-markers; cancer vaccine; colorectal cancer; K-ras; thymidylate synthase

Received: August 24, $2017 \quad$ Accepted: February 21, $2018 \quad$ Published: April 17, 2018

Copyright: Correale et al. This is an open-access article distributed under the terms of the Creative Commons Attribution License 3.0 (CC BY 3.0), which permits unrestricted use, distribution, and reproduction in any medium, provided the original author and source are credited.

\section{ABSTRACT}

TSPP is an anticancer poly-epitope peptide vaccine to thymidylate synthase, recently investigated in the multi-arm phase Ib TSPP/VAC1 trial. TSPP vaccination induced immune-biological effects and showed antitumor activity in metastatic colorectal cancer ( $\mathrm{MCRC}$ ) patients and other malignancies. Progression-free and overall survival of 41 mCRC patients enrolled in the study correlated with baseline levels of CEA, immune-inflammatory markers (neutrophil/lymphocyte ratio, CRP, ESR, LDH, ENA), IL-4 and with post-treatment change in p-ANCA and CD56 ${ }^{\mathrm{dim}}$ CD16 ${ }^{\text {bright }}$ KKs $(p<0.04)$. A subset of 19 patients with activating $k$-ras mutations showed a different immune-inflammatory response to TSPP as compared to patients with k-ras/wt and a worse outcome in term of PFS $(p=0.048)$. In patients with $k$-ras/mut, inflammatory markers lost their predictive value and their survival directly correlated with the baseline levels of IL17/A over the median value $(p=0.01)$. These results provide strong hints for the design of further clinical trials aimed to test TSPP vaccination in $\mathrm{mCRC}$ patients. 


\section{INTRODUCTION}

Thymidylate-synthase poly-epitope peptide (TSPP) is a 27 -mer vaccine construct which contains the amino-acidic sequences of three known cytotoxicT-lymphocyte (CTL) epitopes with HLA-A $(*) 02.01$ amino-acid anchorage motifs (TS-1, TS-2, and TS-3) derived from the thymidylate synthase (TS) and showing promising antitumor activity in preclinical models [1-4]. TS is a cancer-associated target enzyme, critical for DNA replication and repair, commonly overexpressed in proliferating cancer cells, and inhibited by 5 -FU metabolites and other anti-cancer drugs [1-3].

Several studies suggest that cytotoxic drugs like oxaliplatin, gemcitabine, 5-FU or cyclophosphamide, mAbs to EGFR and VEGF, as well as radiotherapy, may induce immunogenic cell death, and shape mCRC microenvironmental conditions making the residual tumor tissue more sensitive to activated immune-effectors. On these bases, our group investigated the antitumor activity and the toxicity of the TSPP vaccination alone and in combination with 5-FU in HLA-A $(*) 02.01$ (HHD) transgenic mice inoculated subcutaneously with TS-expressing EL-4/ HHD lymphoma cells. In these in vivo models, TSPP was able to elicit a specific CTL response without inducing autoimmunity or toxicity and showed a higher antitumor activity in combination with 5-FU [2]. Successively, TSPP was tested in $a$ multi-arm phase Ib (TSPP/VAC-1) trial in metastatic pretreated cancer patients with different malignancies, including metastatic colorectal carcinoma (mCRC) and non-small-cell-lung-cancer (NSCLC) $[5,6]$. The trial investigated the effects of TSPP vaccination alone (arm-A) or associated with granulocyte macrophagecolony-stimulating-factor (GM-CSF) and interleukin-2 (IL-2) (arm-B) [5, 7], or in concomitant (Arm-C/DL1-3) or sequential (arm-C/DL0) combination with a previously characterized $[5,6]$ chemo-immunotherapy regimen with gemcitabine, oxaliplatin, levo-folinic acid (FA) and bolus/ infusional 5-FU followed by IL-2 and GM-CSF (GOLFIG regimen) [6, 8-11]. The study enrolling 50 patients (12 in the $\operatorname{arm}$ A, 9 in the $\operatorname{arm~B,~and~} 29$ in the $\operatorname{arm}$ C) showed that TSPP is safe (MTD was not achieved), exerts immunemodulating effects and produces self-limiting auto-immunity signs in all of the experimental arms. Specifically, TSPP vaccination elicited TS-specific-T cell response and was associated to a progressive rise in serum auto-antibodies [Anti-nuclear anti-bodies (ANA), anti-extractable nuclear antigen (ENA), anti-neutrophil cytoplasmic antibodies/ anti-proteinase-3 (pANCA), and anti-myeloperoxidase (cANCA)] [5, 6]. This study reported preliminary evidence of TSPP antitumor activity on $\mathrm{mCRC}$ patients representing the majority of patient population $[5,6]$ and granting the rationale to design further phase II trials. We, therefore, attempted to identify potential biomarkers predictive of treatment response to TSPP by carrying -out a retrospective analysis on a cohort of $41 \mathrm{mCRC}$ patients enrolled in the TSPP/VAC1 trial.

\section{RESULTS}

\section{Demographics, chemo-immunotherapy, peptide vaccination and dose-escalation}

Forty-one mCRC patients, enrolled in the TSPP/ VAC1 multi-arm phase-Ib trial between May 2011 and July 2013, were considered for this study. TSPP resulted safe and able to induce immune-modulatory activity, including changes in serum levels of multiple inflammatory markers (CRP, ESR, LDH/NV), Auto-antibodies (ANA, ENA, p-ANCA, and c-ANCA) and TSPP-specific CTL precursors' frequency. Th1/Th2/Th17 cytokine profile, blood cell counts, peripheral lymphocyte subsets, DCs and MDSCs showed minimal difference among the three study arms. The population of $\mathrm{mCRC}$ patients enrolled in the trial was homogeneous in term of clinical and immunebiological features and previous treatments (Table 1). All patients were required to present high tumor expression of TS at baseline, while a subgroup of 19 patients (46.3\%) also presented an activating k-ras mutation.

\section{Pathology study}

An immune-histochemical primary tumor analysis in patients bearing wild type k-ras (k-ras/wt) (22 cases) or activating K-ras mutations (K-ras/mut) (19 cases) prior vaccination, revealed no significant difference concerning TS expression (score of expression: 30 for overall, 28 for $\mathrm{K}$-ras/wt and 33 for K-ras/mut ) (Figure 1A) and tumor infiltration by $\mathrm{CD}^{+}, \mathrm{CD}^{+}, \mathrm{CCR} 7^{+} \mathrm{T}$ cells and $\mathrm{T}_{\mathrm{reg}} \mathrm{S}$ (Figure 1B). A lower infiltration score of inflammatory $\mathrm{CD} 15^{+}$cells was conversely found in patients with k-ras/ mut (Figure 1B). It was also observed a significant post-treatment decrement in TS expression in the tumor samples of 10 patients undergone biopsy or surgery after multiple TSPP vaccinations [baseline versus (vs.) posttreatment values: $30.2 \pm 4.69$ vs. $3.7 \pm 0.98 ; P=0.011$ ). Other post-treatment correlations (tumor infiltration by immune-cell subsets and k-ras stratification) could not be performed for inadequacy of biological material.

\section{Immune-monitoring}

Our immune-biological analysis did not reveal differences between patients with k-ras/wt and k-ras/mut, in term of inflammatory markers, peripheral immune-cell subsets and cytokine immune-profile at baseline (Figure $1 \mathrm{C}-1 \mathrm{~F})$. There was a general rise in CRP, c-ANCA, p-ANCA, ENA, and $\mathrm{T}_{\mathrm{reg}} \mathrm{S}$ and $\mathrm{T}_{\mathrm{cm}} \mathrm{s}, \mathrm{IFNy}, \mathrm{IL12} / \mathrm{A}$, and IL10 in the whole patients' population (Figure 1D-1F). On the other hand, patients with k-ras/mut showed greater and progressive rise in the peripheral levels of IFN $\gamma, \mathrm{TNF} \alpha$, and IL17/A, a significant increase in peripheral $\mathrm{T}_{\mathrm{cm}} \mathrm{s}$, and $\mathrm{T}_{\text {reg }} \mathrm{s}$, and no change in the levels of cANCA and ENA, which conversely, resulted largely increased in patients 
Table 1: Demographic, clinical and molecular pathology characteristics of the patients enrolled in the clinical trial

\begin{tabular}{|c|c|c|c|c|c|c|c|c|c|}
\hline CODE & Sex & ECOG & Metastatic sites & $\begin{array}{c}\text { Previous } \\
\text { treatment lines }\end{array}$ & K-ras & HLA & $\begin{array}{c}\text { Treatment } \\
\text { courses }\end{array}$ & MANT & $\begin{array}{l}\text { Type of } \\
\text { response }\end{array}$ \\
\hline MFA/A/DL1 & F & 0 & Liver, lung & 11 & $\mathrm{Wt}$ & $\mathbf{A 2}$ & 3 & $\mathrm{Na}$ & $\mathrm{SD}$ \\
\hline RAA/A/DL1 & $\mathrm{F}$ & 0 & $\begin{array}{l}\text { Peritoneum, } \\
\text { nodes }\end{array}$ & 7 & $\mathrm{Wt}$ & $\mathbf{A 2}$ & 3 & $\mathrm{Na}$ & $\mathrm{PD}$ \\
\hline ASA/A/DL1 & M & 0 & Liver, Lung & 3 & $\mathrm{Wt}$ & $\mathbf{A 2}$ & 3 & $\mathrm{Na}$ & SD \\
\hline LVA/A/DL2 & M & 0 & $\begin{array}{l}\text { Liver, Lung, } \\
\text { nodes }\end{array}$ & 7 & $\mathrm{Wt}$ & A11 & 6 & $\mathrm{Na}$ & SD \\
\hline SGA/A/DL2 & M & 0 & $\begin{array}{l}\text { Peritoneum, } \\
\text { nodes }\end{array}$ & 4 & $\mathrm{Wt}$ & A 25 & 6 & $\mathrm{Na}$ & $\mathrm{SD}$ \\
\hline ZSA/A/DL3 & $\mathrm{F}$ & 0 & Nodes, Adrenal & 3 & $\mathrm{Wt}$ & $\mathbf{A 2}$ & 48 & $\mathrm{Na}$ & PR \\
\hline PNA/A/DL3 & $\mathrm{F}$ & 0 & Lung, bones & 3 & Mut & A1 & 3 & $\mathrm{Na}$ & $\mathrm{SD}$ \\
\hline SNA/A/DL3 & M & 2 & Liver, lung & 3 & Mut & $\mathbf{A 2}$ & 3 & $\mathrm{Na}$ & $\mathrm{PD}$ \\
\hline GL/B/DL2 & $\mathrm{F}$ & 0 & Liver, abdomen & 3 & Mut & A24 & 3 & $\mathrm{Na}$ & PD \\
\hline $\mathrm{PP} / \mathrm{B} / \mathrm{DL} 2$ & $\mathrm{~F}$ & 0 & $\begin{array}{l}\text { Lung, liver } \\
\text { abdomen }\end{array}$ & 3 & $\mathrm{Wt}$ & $\mathbf{A 2}$ & 3 & $\mathrm{Na}$ & $\mathrm{SD}$ \\
\hline FG/B/DL2 & M & 0 & $\begin{array}{l}\text { Abdomen, } \\
\text { nodes }\end{array}$ & 3 & $\mathrm{Wt}$ & A24 & 3 & $\mathrm{Na}$ & $\mathrm{PD}$ \\
\hline $\mathrm{MM} / \mathrm{B} / \mathrm{DL} 3$ & M & 1 & $\begin{array}{l}\text { Lung, liver } \\
\text { abdomen }\end{array}$ & 3 & Mut & A1 & 3 & $\mathrm{Na}$ & SD \\
\hline $\mathrm{LM} / \mathrm{C} / \mathrm{DL} 1$ & F & 2 & $\begin{array}{l}\text { Peritoneum, } \\
\text { lung, liver }\end{array}$ & 2 & Mut & A24 & 7 & 2 & $\mathrm{SD}$ \\
\hline $\mathrm{CV} / \mathrm{C} / \mathrm{DL} 1$ & M & 1 & $\begin{array}{l}\text { Peritoneum, } \\
\text { lung, liver }\end{array}$ & 6 & Mut & A3 & 6 & 0 & PD \\
\hline $\mathrm{BF} / \mathrm{C} / \mathrm{DL} 1$ & M & 2 & $\begin{array}{l}\text { Peritoneum, } \\
\text { lung, liver }\end{array}$ & 3 & Mut & A11 & 3 & 0 & PD \\
\hline $\mathrm{CL} / \mathrm{C} / \mathrm{DL} 2$ & $\mathrm{~F}$ & 0 & $\begin{array}{l}\text { Peritoneum, } \\
\text { nodes }\end{array}$ & 3 & Mut & $\mathbf{A 2}$ & 12 & 1 & PD \\
\hline $\mathrm{FA} / \mathrm{C} / \mathrm{DL} 2$ & $\mathrm{~F}$ & 2 & $\begin{array}{l}\text { Colon, lung, } \\
\text { liver }\end{array}$ & 6 & $\mathrm{Wt}$ & A11 & 11 & 0 & SD \\
\hline $\mathrm{SA} / \mathrm{C} / \mathrm{DL} 2$ & M & 0 & $\begin{array}{l}\text { Lung, liver, } \\
\text { nodes }\end{array}$ & 5 & $\mathrm{Wt}$ & A2 & 12 & 2 & PR \\
\hline $\mathrm{SS} / \mathrm{C} / \mathrm{DL} 3$ & F & 0 & $\begin{array}{l}\text { Brain, lung, } \\
\text { liver, nodes }\end{array}$ & 5 & Mut & $\mathrm{A} 23$ & 12 & 3 & PR \\
\hline $\mathrm{BA} / \mathrm{C} / \mathrm{DL} 3$ & F & 1 & $\begin{array}{l}\text { Colon, lung, } \\
\text { liver, nodes }\end{array}$ & 2 & Mut & $\mathbf{A 2}$ & 11 & 0 & SD \\
\hline $\mathrm{SA} / \mathrm{C} / \mathrm{DL} 3$ & F & 2 & $\begin{array}{l}\text { Peritoneum, } \\
\text { lung, liver }\end{array}$ & 5 & Mut & A2 & 12 & 0 & PD \\
\hline $\mathrm{DA} / \mathrm{C} / \mathrm{DL} 3$ & $\mathrm{~F}$ & 2 & $\begin{array}{l}\text { Peritoneum, } \\
\text { lung, liver }\end{array}$ & 4 & Mut & $\mathrm{A} 1$ & 10 & 0 & PD \\
\hline $\mathrm{MP} / \mathrm{C} / \mathrm{DL} 3$ & M & 1 & $\begin{array}{l}\text { Peritoneum, } \\
\text { lung, liver }\end{array}$ & 6 & Mut & A2 & 6 & 0 & SD \\
\hline $\mathrm{PM} / \mathrm{C} / \mathrm{DL} 3$ & M & 1 & $\begin{array}{l}\text { Peritoneum, } \\
\text { lung, liver }\end{array}$ & 2 & Mut & A11 & 12 & 3 & SD \\
\hline MU/C/DL3 & F & 1 & $\begin{array}{l}\text { Soft tissue, } \\
\text { nodes }\end{array}$ & 2 & $\mathrm{Wt}$ & A24 & 12 & 14 & SD \\
\hline
\end{tabular}




\begin{tabular}{|c|c|c|c|c|c|c|c|c|c|}
\hline $\mathrm{PA} / \mathrm{C} / \mathrm{DL} 3$ & M & 1 & $\begin{array}{l}\text { Peritoneum, } \\
\text { lung, liver }\end{array}$ & 7 & $\mathrm{Wt}$ & A2 & 11 & 3 & PR \\
\hline $\mathrm{CA} / \mathrm{C} / \mathrm{DL} 3$ & M & 2 & $\begin{array}{l}\text { Peritoneum, } \\
\text { lung, liver }\end{array}$ & 3 & Mut & NA & 6 & 0 & $\mathrm{PD}$ \\
\hline BG/C/DL3 & $\mathrm{F}$ & 0 & $\begin{array}{l}\text { Peritoneum, } \\
\text { lung, liver }\end{array}$ & 3 & Wt & A2 & 10 & 8 & SD \\
\hline NR/C/DL3 & $\mathrm{F}$ & 2 & $\begin{array}{l}\text { Peritoneum, } \\
\text { lung, liver }\end{array}$ & 2 & Mut & A2 & 3 & 0 & PD \\
\hline SR/C/DL0 & M & 0 & Lung, liver & 3 & Wt & A 23 & 12 & 5 & SD \\
\hline DG/C/DL0 & $\mathrm{F}$ & 0 & Lung, liver & 3 & $\mathrm{Wt}$ & A33 & 10 & 5 & PR \\
\hline $\mathrm{BL} / \mathrm{C} / \mathrm{DL} 0$ & $\mathrm{~F}$ & 0 & Lung, liver & 2 & $\mathrm{Wt}$ & $\mathrm{A} 3$ & 10 & 9 & SD \\
\hline $\mathrm{ML} / \mathrm{C} / \mathrm{DL0}$ & $\mathrm{F}$ & 0 & $\begin{array}{l}\text { Peritoneum, } \\
\text { lung, liver }\end{array}$ & 2 & Mut & A2 & 10 & 9 & SD \\
\hline $\mathrm{VP} / \mathrm{C} / \mathrm{DL} 0$ & M & 1 & lung, liver & 2 & Wt & $\mathbf{A 2}$ & 7 & 1 & PD \\
\hline PG/C/DL0 & M & 1 & lung, liver & 2 & $\mathrm{Wt}$ & A 24 & 9 & 12 & SD \\
\hline $\mathrm{SA} / \mathrm{C} / \mathrm{DL} 0$ & M & 2 & $\begin{array}{l}\text { Peritoneum, } \\
\text { lung, liver }\end{array}$ & 3 & $\mathrm{Wt}$ & $\mathrm{A} 1$ & 7 & 0 & PD \\
\hline $\mathrm{MA} / \mathrm{C} / \mathrm{DL} 0$ & M & 0 & lung, liver & 2 & Mut & $\mathrm{A} 1$ & 9 & 32 & PR \\
\hline $\mathrm{PA} / \mathrm{C} / \mathrm{DL} 0$ & M & 0 & lung, liver & 2 & $\mathrm{Wt}$ & A3 & 11 & 14 & PR \\
\hline DL/C/DL0 & $\mathrm{F}$ & 0 & $\begin{array}{l}\text { Peritoneum, } \\
\text { lung, liver }\end{array}$ & 3 & $\mathrm{Wt}$ & A2 & 9 & 4 & SD \\
\hline $\mathrm{VC} / \mathrm{C} / \mathrm{DL} 0$ & M & 0 & $\begin{array}{l}\text { Peritoneum, } \\
\text { lung, liver }\end{array}$ & 2 & mut & A23 & 10 & 7 & PR \\
\hline $\mathrm{PA} / \mathrm{C} / \mathrm{DL} 0$ & $\mathrm{~F}$ & 1 & $\begin{array}{l}\text { Peritoneum, } \\
\text { lung, liver }\end{array}$ & 3 & $\mathrm{Wt}$ & A 23 & 9 & 4 & SD \\
\hline
\end{tabular}

Legend: ECOG, Eastern Cooperative Oncology Group performance status; Wt, Wild type; Mut, Mutated; SD, Stabilized Disease; PR, Partial Response; PD, Progressive Disease; MANT, Maintainance Therapy duration in months; Na; not achieved.

with k-ras/wt (Figure 1D-1F). No significant differences were recorded for NEUTR, LINF, CD4+, CD8+, and $\mathrm{T}_{\mathrm{em}} \mathrm{s}$.

\section{Patients' outcome correlations}

The impact of these inflammatory and immunological parameters (Table 2) on the outcome of TSPP vaccinated patients was also investigated. Altogether, these patients presented an OS of $14.902 \pm 2.575$ (95\% CI 9.85-19.85) months, with 13 out of 41 cases surviving more than 12 months. In our series, PFS and OS were inversely correlated with the baseline performance status (ECOG score) and CEA levels. Patients with k-ras/mut presented a worse outcome with shorter PFS (Table 3) and no differences in OS. We did not find significant differences when PFS and OS were correlated with the number of previous treatment lines, age, gender, HLA-A $\left(^{*}\right) 02.01$ haplotype, and TS-and immune-cell tumor infiltration scores, TS score change after treatment (data not shown).

Patients in the arm C/DL-0 (GOLFIG chemoimmunotherapy followed by TSPP vaccine) showed the longest survival over the other treatment groups [arm C/ DL0 vs arm A, B, and C/DL 1-3; log Rank test, $p=0.03$ and Breslow (Generalized Wilcoxon) test, $P=0.021$ ] even though these results should be taken cautiously for the very small statistical sample (Figure 2B). Our statistical analysis also revealed that patients' PFS and OS correlated with lower baseline levels of neutrophils, NLR, CRP, ESR, LDH/ NV, ENA and IL4. PFS and OS also correlated with no posttreatment increases $(\mathrm{FBV}>1)$ of the same inflammatory markers. Finally, a prolonged survival was also recorded in patients presenting a treatment-related increase (FBV > 1) of pANCA and highly cytotoxic NK (CD56 $\left.{ }^{\text {dim }} \mathrm{CD} 16^{\text {brigth }}\right)$ cells (Table 4). On the overall population, we were unable to find any significant correlation of either PFS or OS with the baseline values and post-treatment changes of TSspecific CTL precursor frequency, TNF $\alpha$, IL12p70, IFN $\gamma$, IL10,IL17, CD4 ${ }^{+}, \mathrm{CD}^{+}, \mathrm{T}_{\mathrm{cm}} \mathrm{s}, \mathrm{T}_{\mathrm{em}} \mathrm{s}, \mathrm{T}_{\mathrm{reg}} \mathrm{s}, \mathrm{DCs}, \mathrm{MDSCs}$ (Table 4 and data not shown).

\section{Predictive markers in patients who received TSPP \pm cytokines and TSPP + GOLFIG chemo- immunotherapy}

Then, the predictive values of these inflammatory and immunological parameters was separately 
investigated in patients receiving TSPP vaccine ( \pm cytokines) alone or together with cytotoxic drugs. The two groups did not show difference in term of survival $[\operatorname{arm} \mathrm{A}+\mathrm{B}$ vs C/DL0 + C/DL1-3: $13.49 \pm 4.89(95 \%$ CI 3.92-23.07) vs. $14.62 \pm 2.45$ (95\% CI 9.82-19.42); $p=0.29]$ (Figure 2A). On the other hand, those patients who received the sequential treatment (arm C/DL0) with GOLFIG followed by TSPP vaccination showed the longest survival over the other groups $(p=0.03)$ (Figure 2B). First of all, a longer survival in patients with lower NLR, independently by the treatment arm, was confirmed ( $p=0.016$ ) (Figure $2 \mathrm{C}-2 \mathrm{D})$. We also reported that a lower $\mathrm{T}_{\text {reg }}$ expression at baseline showed a trend to longer survival in both groups $(\operatorname{arm} \mathrm{A}+\operatorname{arm} \mathrm{B}: p=$
0.062) (arm C DL1-3 and DL0: $p=0.088$ ) (Figure 2E2F). Moreover, we observed that higher IL17/A levels at baseline correlated with longer survival in the group of patients enrolled in the arm C (DL0-3: $p=0.017$ ) only, with no correlation in the other group ( $\operatorname{arm} \mathrm{A}+\mathrm{B}$ : $p=0.253$ ) (Figure $2 \mathrm{G}-2 \mathrm{H}$ ). In order to identify specific inflammatory immunological signatures predictive of response to TSPP vaccination we assembled and tested an inflammation-score. It was composed by assigning an arbitrary value to specific inflammatory parameters at baseline. Each parameter (ESR, CPR and LDH/NV) was categorized as zero, when it was $<$ the specific median value and 1 if it was $\geq$ the median value. The inflammatory score derived from the sum of the three
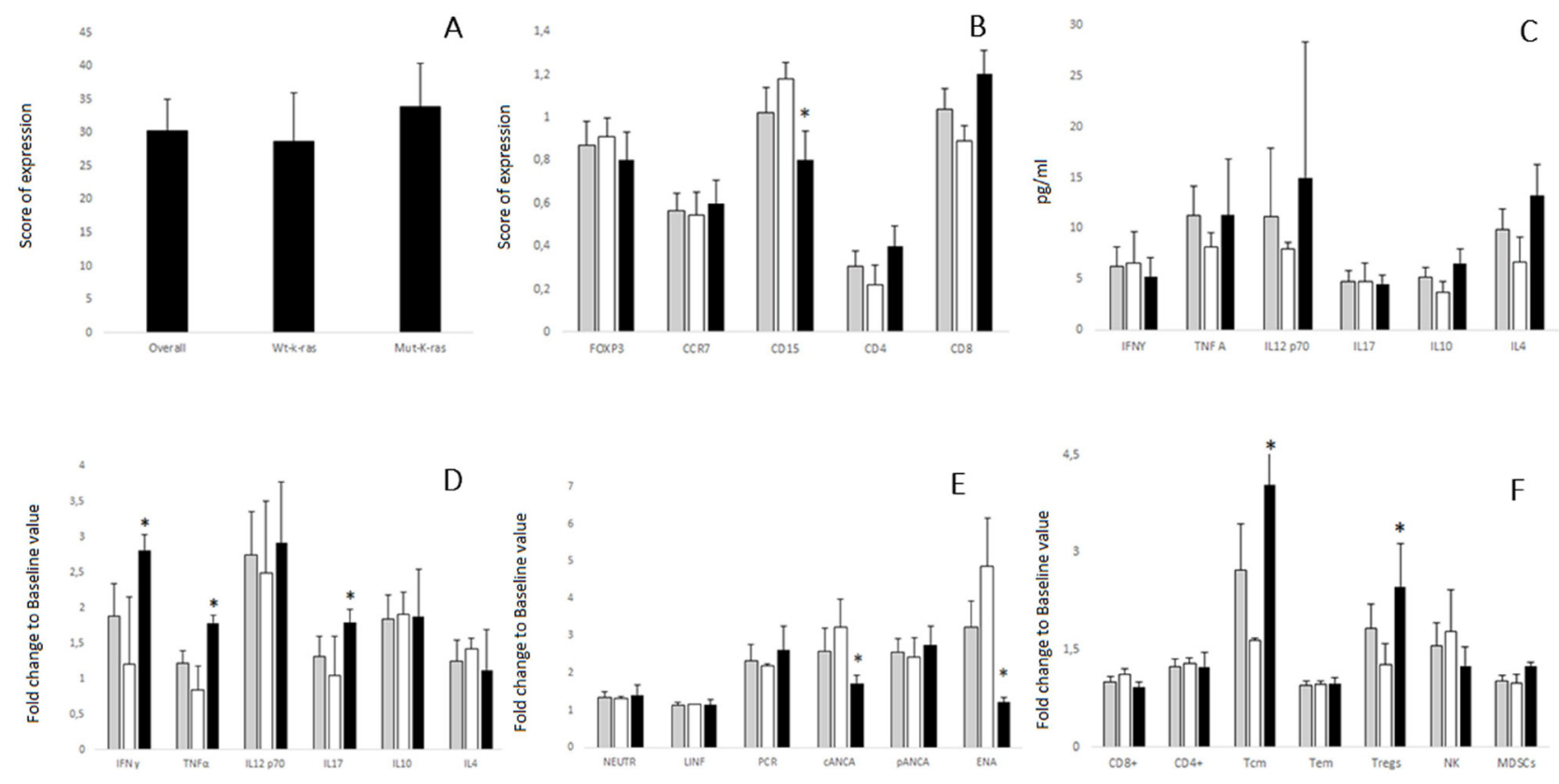

Figure 1: (A) Immuno-histochemical analysis of TS expression in the primary tumor of $41 \mathrm{mCRC}$ patients enrolled in the TSPP/VAC1trials [All patients (overall), patients with k-ras wt (wt-k-ras) and patients with mutated k-ras (mut-k-ras)]. Results are expressed as number of positive cells per HPF ( \pm SE). No difference in TS expression was detected between the two subsets of patients. (B) Immunohistochemical analysis of tumor infiltrating $\mathrm{T}$ cells expressing FoxP3 $\left(\mathrm{T}_{\mathrm{reg}}\right), \mathrm{CCR} 7\left(\mathrm{~T}_{\mathrm{cm} / \mathrm{em}}\right), \mathrm{CD} 4$, or CD8 and inflammatory cells expressing CD15. This analysis was carried out in the primary tumor of $41 \mathrm{mCRC}$ patients who received TSPP vaccine ["], whose 22 with k-ras wt [ $\square$ ] and 19 with mutated k-ras [ $\mathbf{\square}$. Results are expressed as number of positive cells per HPF ( \pm SE). No differences were detected between the two subsets of patients with exception of CD15 cells, which showed a reduced expression in patients with k-ras mut $(P=0.046)$, Asterisk ( $\left.{ }^{*}\right)$ represents statistically significant difference. (C) Cytokine Multiplex analysis- Evaluation of baseline serum levels of IFNy, TNF $\alpha$, IL12p70, IL17/A, IL10, IL4 of $41 \mathrm{mCRC}$ patients who received TSPP vaccine $41 \mathrm{mCRC}$ patients who received TSPP vaccine [!], wt [ $\square]$ and 19 with mutated k-ras $[\square]$. Results are $\mathrm{pg} / \mathrm{ml}( \pm \mathrm{SE})$. No differences were detected between the two subsets of patients at baseline. (D) Evaluation of fold change to baseline values of serum levels of IFNy, TNF $\alpha$, IL12p70, IL17/A, IL10, and IL4 of 41 mCRC patients who received TSPP vaccine [[], whose 22 with k-ras wt [ $\square]$ and 19 with mutated k-ras [-]. Results are expressed as fold induction relative to baseline indicated as $1( \pm \mathrm{SE})$. Asterisk $\left(^{*}\right)$ represents statistical significance to between k-ras mut vs k-ras wtpatients $(P<0.05)$; hashtag $\left(\left(^{*}\right)\right.$ represents statistical significance to baseline value $(P<0.05)$. (E) Evaluation of fold change to baseline values of Neutrophils, lymphocytes, CRP, cANCApANCA and ENA of 41 mCRC patients who received TSPP vaccine []], whose 22 with k-ras wt [ $\square$ ] and 19 with mutated k-ras [-]. Results are expressed as fold induction relative to baseline indicated as $1\left( \pm\right.$ SE). Asterisk $\left(^{*}\right)$ represents statistical significance to between k-ras mut vs k-ras wt patients $(P<0.05)$; hashtag $\left(^{\#)}\right.$ represents statistical significance to baseline value $(P<0.05)$. (F) Flow cytometry- Evaluation of fold change to baseline levels of peripheral blood cells expressing the following phenotypes: $\mathrm{CD}^{+} \mathrm{CD}^{+}$,

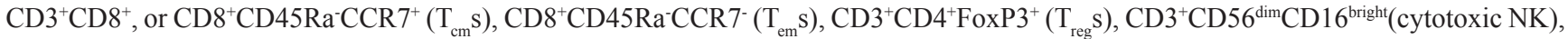
and myeloid derivative suppressive cells (MDSCs). This analysis was performed on $41 \mathrm{mCRC}$ patients who received TSPP vaccine [[], whose 22 with k-ras wt [ $\square]$ and 19 with mutated k-ras [ $[\mathbf{\square}$. Results are expressed as fold induction relative to baseline indicated as 1 ( \pm $\mathrm{SE})$. Asterisk $\left(^{*}\right)$ represents statistical significance to between k-ras mut vs k-ras wt patients $(P<0.05)$; hashtag $\left(^{*}\right)$ represents statistical significance to baseline value $(P<0.05)$. 
Table 2: Immunophenotypic characteristics and serum molecular markers and auto-antibodies of the patients

\begin{tabular}{|c|c|c|c|c|c|c|c|}
\hline & Neu & Lymph & \multicolumn{2}{|c|}{ NLR } & \multicolumn{2}{|c|}{ ESR } & LDH/N \\
\hline Overall & $\begin{array}{c}3650 \\
(278,2)\end{array}$ & $\begin{array}{c}1571 \\
(118,4)\end{array}$ & \multicolumn{2}{|c|}{$\begin{array}{l}2,609 \\
(0,22)\end{array}$} & \multicolumn{2}{|c|}{$68(5.3)$} & $\begin{array}{l}1,481 \\
(0,16)\end{array}$ \\
\hline Wt-k-ras & $\begin{array}{c}3456 \\
(507,9)\end{array}$ & $\begin{array}{c}1581 \\
(41,7)\end{array}$ & \multicolumn{2}{|c|}{$\begin{array}{l}2,512 \\
(0,45)\end{array}$} & \multicolumn{2}{|c|}{$56,5(6.8)$} & $\begin{array}{l}1,365 \\
(0,26)\end{array}$ \\
\hline Mut-k-ras & $\begin{array}{c}3939 \\
(368,7)\end{array}$ & $\begin{array}{c}1636 \\
(171,7) \\
\end{array}$ & \multicolumn{2}{|c|}{$\begin{array}{c}2,748 \\
(0,3) \\
\end{array}$} & \multicolumn{2}{|c|}{$68(7.8)$} & $\begin{array}{c}1,601 \\
(0,2)\end{array}$ \\
\hline & & CEA & \multicolumn{2}{|r|}{ c-ANCA } & p-ANCA & \multicolumn{2}{|c|}{ ENA } \\
\hline Overall & & $\begin{array}{c}122,5 \\
(211.8)\end{array}$ & \multicolumn{2}{|r|}{$\begin{array}{c}0,921 \\
(0,1)\end{array}$} & $\begin{array}{c}0,688 \\
(0,08)\end{array}$ & \multicolumn{2}{|c|}{$\begin{array}{l}0,324 \\
(0,04)\end{array}$} \\
\hline Wt-k-ras & & $\begin{array}{c}180.5 \\
(383.3)\end{array}$ & \multicolumn{2}{|r|}{$\begin{array}{c}1,086 \\
(0,1)\end{array}$} & $\begin{array}{l}0,729 \\
(0,21)\end{array}$ & \multicolumn{2}{|c|}{$\begin{array}{l}0,337 \\
(0,02)\end{array}$} \\
\hline Mut-K-ras & & $\begin{array}{c}122,5 \\
(127.8)\end{array}$ & \multicolumn{2}{|r|}{$\begin{array}{l}0,763 \\
(0,08)\end{array}$} & $\begin{array}{c}0,625 \\
(0,08)\end{array}$ & \multicolumn{2}{|c|}{$\begin{array}{l}0,326 \\
(0,05)\end{array}$} \\
\hline & $\mathrm{CD4}^{+}$ & $\mathrm{CD8}^{+}$ & $T_{\mathrm{reg}}$ & $T_{\mathrm{cm}}$ & $\mathbf{T}_{\mathrm{em}}$ & c-NK & MDSCs \\
\hline Overall & $40,1(2,6)$ & $26,9(1,7)$ & $3,2(0,44)$ & $6,3(1,39)$ & $40,3(3,26)$ & $9.63(3,36)$ & $3.95(1,97)$ \\
\hline Wt-k-ras & $38,2(1,8)$ & $25,7(2,1)$ & $3,2(0,05)$ & $4,7(0,09)$ & $44,7(2,2)$ & $7.57(4,45)$ & $4.47(1,47)$ \\
\hline Mut-K-ras & $44,2(3,3)$ & $29,6(2,8)$ & $3,5(0,7)$ & $8,57(2,67)$ & $37,2(5,06)$ & $11.7^{*}(4,13)$ & $3.55(2,1)$ \\
\hline
\end{tabular}

parameters' values. When a statistical analysis was carried out a low inflammation-score $(<2)$ was highly predictive of longer survival in patients enrolled in arm A and B [high $v s$. low score $(<2)$ high vs. low score: $p=0.049)$ while it showed no significance in patients enrolled in the arm C (high vs. Low score: $p=0.199$ ) (Figure 2B).

\section{Predictive markers in $\mathrm{mCRC}$ patients with $\mathrm{k}-\mathrm{ras} / \mathrm{wt}$ and $\mathrm{k}-\mathrm{ras} / \mathrm{mut}$ who received TSPP vaccine}

Finally our analysis revealed that either inflammatory or immunological parameters, and independently by the treatment arm, showed substantial differences when respectively, correlated with OS in patients bearing k-ras/mut.

In particular, in the latter group of patients the predictive value of ESR, CRP, LDH/NV and ENA levels at baseline was lost in term of survival.

Additionally, we found the OS of patients with k-ras/wt, and not those with k-ras/mut, was specifically correlated with baseline IL12/p70 levels lower than the median value $(p=0.034)$, while the OS of patients with k-ras/mut, and not those with k-ras/wt, specifically correlated with the baseline IL17/A levels over the median value $(p=0.01)$ (Table 5 and Figure 3$)$.

\section{DISCUSSION}

The results of the TSPP/VAC 1 trial suggested that TSPP vaccination is safe, induces immune-modulatory effects and exerts antitumor activity in 41 pretreated $\mathrm{mCRC}$ patients (third/fourth treatment line), who showed a PFS and OS of 6.9 and 14.9 months, respectively. These results can be considered very encouraging at the light of the fact that Regorafenib, the multi-kinase inhibitor currently recommended for salvage treatment of pretreated $\mathrm{mCRC}$, is associated to a PFS and OS, respectively of 2 and 6.4 months, with significant adverse events and very high costs [12]. These results in mCRC patients may also be of interest considering that $\mathrm{mCRC}$-immunotherapy has been a dynamic field of investigation for more than 30 years with controversial results in term of antitumor activity [13, 14]. In fact, results of several immunotherapy trials have shown that it is possible to use different antigen vectors to trigger an efficient $\mathrm{T}$ cells response to tumor associate antigens such as CEA, MUC-1, k-ras/mut in mCRC patients [13]. Nevertheless, even in the presence of a significant treatment-induced $\mathrm{T}$ cell response, none of these agents has been able to improve the outcome of these patients [13]. Several reasons have been advocated to explain these negative results, including the poor immunogenicity of the target antigens and/or failures in the delivery constructs, 
Table 3: Statistical evaluation of the correlation between clinical/tumor-associated markers and the clinical outcome of the patients

\begin{tabular}{|c|c|c|c|c|c|}
\hline Comparative marker & Cut-off value & Number of patients & Months \pm SD & Endpoint & $P$ value \\
\hline ECOG & $\begin{array}{l}\leq 1 \\
>2\end{array}$ & $\begin{array}{l}29 \\
10\end{array}$ & $\begin{array}{l}9,31 \pm 2,27 \\
2,41 \pm 0,43\end{array}$ & PFS & $<0.001$ \\
\hline ECOG & $\begin{array}{l}\leq 1 \\
>2\end{array}$ & $\begin{array}{l}29 \\
10\end{array}$ & $\begin{array}{c}17,04 \pm 2,97 \\
3,91 \pm 0,74\end{array}$ & OS & $<0.001$ \\
\hline \multirow[t]{2}{*}{ CEA } & $\begin{array}{l}\leq \text { median value } \\
>\text { median value }\end{array}$ & $\begin{array}{l}19 \\
17\end{array}$ & $\begin{array}{c}11,05 \pm 3,36 \\
4,41 \pm 0,78\end{array}$ & PFS & 0.189 \\
\hline & $\begin{array}{l}\leq \text { median value } \\
>\text { median value }\end{array}$ & $\begin{array}{l}19 \\
19\end{array}$ & $\begin{array}{c}19,10 \pm 4,19 \\
7,42 \pm 1,14\end{array}$ & OS & 0.021 \\
\hline \multirow[t]{2}{*}{ Sex } & $\begin{array}{l}\text { Male } \\
\text { Female }\end{array}$ & $\begin{array}{l}18 \\
21\end{array}$ & $\begin{array}{c}5.8 \pm 7.2 \\
8.05 \pm 11.6\end{array}$ & PFS & $>0.25$ \\
\hline & $\begin{array}{l}\text { Male } \\
\text { Female }\end{array}$ & $\begin{array}{l}18 \\
21\end{array}$ & $\begin{array}{c}11.44 \pm 10.1 \\
11.8 \pm 12.2\end{array}$ & OS & $>0.25$ \\
\hline \multirow[t]{2}{*}{ Age (years) } & $\begin{array}{l}<50 \\
\geq 50\end{array}$ & $\begin{array}{c}7 \\
32\end{array}$ & $\begin{array}{c}3.71 \pm 2.28 \\
7.75 \pm 10.59\end{array}$ & PFS & $>0.25$ \\
\hline & $\begin{array}{l}<50 \\
\geq 50\end{array}$ & $\begin{array}{c}7 \\
32\end{array}$ & $\begin{array}{c}10.7 \pm 5.43 \\
11.8 \pm 12.11\end{array}$ & OS & $>0.25$ \\
\hline \multirow[t]{2}{*}{ HLA-A2 } & $\begin{array}{l}\text { Positive } \\
\text { Negative }\end{array}$ & $\begin{array}{l}15 \\
20\end{array}$ & $\begin{array}{l}7,46 \pm 2,98 \\
7,10 \pm 2,00\end{array}$ & PFS & 0.764 \\
\hline & $\begin{array}{l}\text { Positive } \\
\text { Negative }\end{array}$ & $\begin{array}{l}15 \\
20\end{array}$ & $\begin{array}{l}12,16 \pm 3,35 \\
13,70 \pm 2,93\end{array}$ & OS & 0.684 \\
\hline \multirow[t]{2}{*}{ K-ras status } & $\begin{array}{l}\text { Wild Type } \\
\text { Mut }\end{array}$ & $\begin{array}{l}22 \\
19\end{array}$ & $\begin{array}{l}8,77 \pm 2,29 \\
4,68 \pm 1,58\end{array}$ & PFS & 0.050 \\
\hline & $\begin{array}{l}\text { Wild Type } \\
\text { Mut }\end{array}$ & $\begin{array}{l}22 \\
19\end{array}$ & $\begin{array}{c}15,98 \pm 3,35 \\
8,64 \pm 2,31\end{array}$ & OS & 0.160 \\
\hline
\end{tabular}

Legend: ECOG, Eastern Cooperative Oncology Group performance status; CEA, Carcino-Embryonic Antigen; Mut, Mutated.

occurrence of immune-suppressive cell lineages $\left(\mathrm{T}_{\text {reg }} \mathrm{s}\right.$, MDSCs, M2-macrophages, etc.), the resistance of CCR cells to the immune-effectors, the interference of multiple immune-checkpoint inhibitors, and finally, a tumorprotective-microenvironment associated with CRC [13]. The latter points in particular have been associated to chronic inflammation, neo-angiogenesis and hypoxia, infiltration by $\mathrm{T}_{\mathrm{reg}} \mathrm{s}$, MDSCs, and other immune-suppressive cell lineages expressing PDL-1 and PDL-2 [15]. More recent immunotherapy approaches involving immunecheckpoint blockade, successful in the treatment of other solid tumors, have instead achieved deluding therapeutic results in mCRC patients [16-20]. In fact, mAbs to CTLA4 resulted completely inactive [15-16], while mAbs to PD-1/PDL1 immune-checkpoint have shown antitumor activity only in a subset of patients with deficient mismatch repair (dMMR). In the latter case, it has been hypothesized that the dMMR status increases the burden of neo-antigens that elicit a very proficient CTL response with potential antitumor activity susceptible to PD-1/PDL1 axis, and consequently, to mAb blockade [16]. All together, these results clearly suggest that immune-checkpoint blockade requires the presence of highly cytotoxic CTLs educated to destroy mCRC cells expressing critical antigens, eventually inhibited in the tumor tissue throughout PD-1 axis, as main mechanism of immune-escape. In this context, the use of TSPP vaccination to elicit a TS specific CTL response prior scheduling PD1/PDL-1blockade could be a very successful treatment strategy to take in consideration for mCRC patients. Additionally, the results of several studies suggest that cytotoxic drugs like oxaliplatin, gemcitabine, 5-FU or cyclophosphamide, mAbs to EGFR and VEGF, as well as radiotherapy, may induce immunogenic cell death, and shape mCRC micro-environmental conditions making the residual tumor tissue more sensitive to activated immuneeffectors [17-20]. On the other hand, previous clinical 
results of our group on the GOLFIG regimen have shown that a rationale combination of chemotherapy and immuneadjuvant cytokinesis are really capable to improve both PFS and OS in mCRC [8-11]. The GOLFIG regimen has been designed to mimic an in vitro procedure to generate very efficient CCR-specific CTLs from human PBMCs and in parallel to shape the residual tumor to become more susceptible to the immune-effector activity [8, 13, 21]. In preclinical models, this multi-drug regimen was able to induce immunogenic cell death in CRC cells, with massive release of TAAs in a context of danger signal and crosspriming, which in turn was able to trigger a multi-antigen specific $\mathrm{T}$ cell response with potent antitumor activity $[8,21]$. In line with these preclinical results, two consecutive phase II and phase III trials showed that the use of this regimen in $\mathrm{mCRC}$ patients, elicits a CEA/TS specific $\mathrm{T}$ cell response, increases the amount of peripheral and central $\mathrm{T}_{\mathrm{cm}} \mathrm{s}$, and in parallel decreases the score of tumor infiltrating $\mathrm{T}_{\text {reg }} \mathrm{s}$ [9-11]. Sixteen percent of the $\mathrm{mCRC}$ patients receiving this treatment, presented autoimmunity, an event which resulted strongly predictive of prolonged
PFS and survival [10]. Based on these immune-adjuvant and immune-shaping properties, the GOLFIG regimen was investigated in concomitant and sequential combination with TSPP in the arm C of TSPP/VAC-1 trial in mCRC patients (arm C/DL1-3 and C/DL0, respectively). Even though the three arms were not designed on comparative setting, those patients who had received TSPP vaccination after multiple GOLFIG courses (arm C/DL0) showed a very promising outcome, with a PFS and OS of 7 and 16 months, respectively $[5,6]$. In line with these data, the results of our study in $\mathrm{mCRC}$ patients undergone TSPP vaccination suggested that the number of previous treatments, age, gender, treatment $\operatorname{arm}(\mathrm{A}, \mathrm{B}$ or $\mathrm{C})$, HLA-A(*)02.01 haplotype, TS levels and TIL immunephenotype in the tumor, at baseline, were not able to influence the outcome of these patients. On the other hand, a good performance status and lower CEA levels at baseline, representative of a smaller tumor burden, were associated to a better outcome. Additionally, the presence of an activating K-ras mutation was associated to a worse outcome in term of PFS and to a trend to a worse survival.
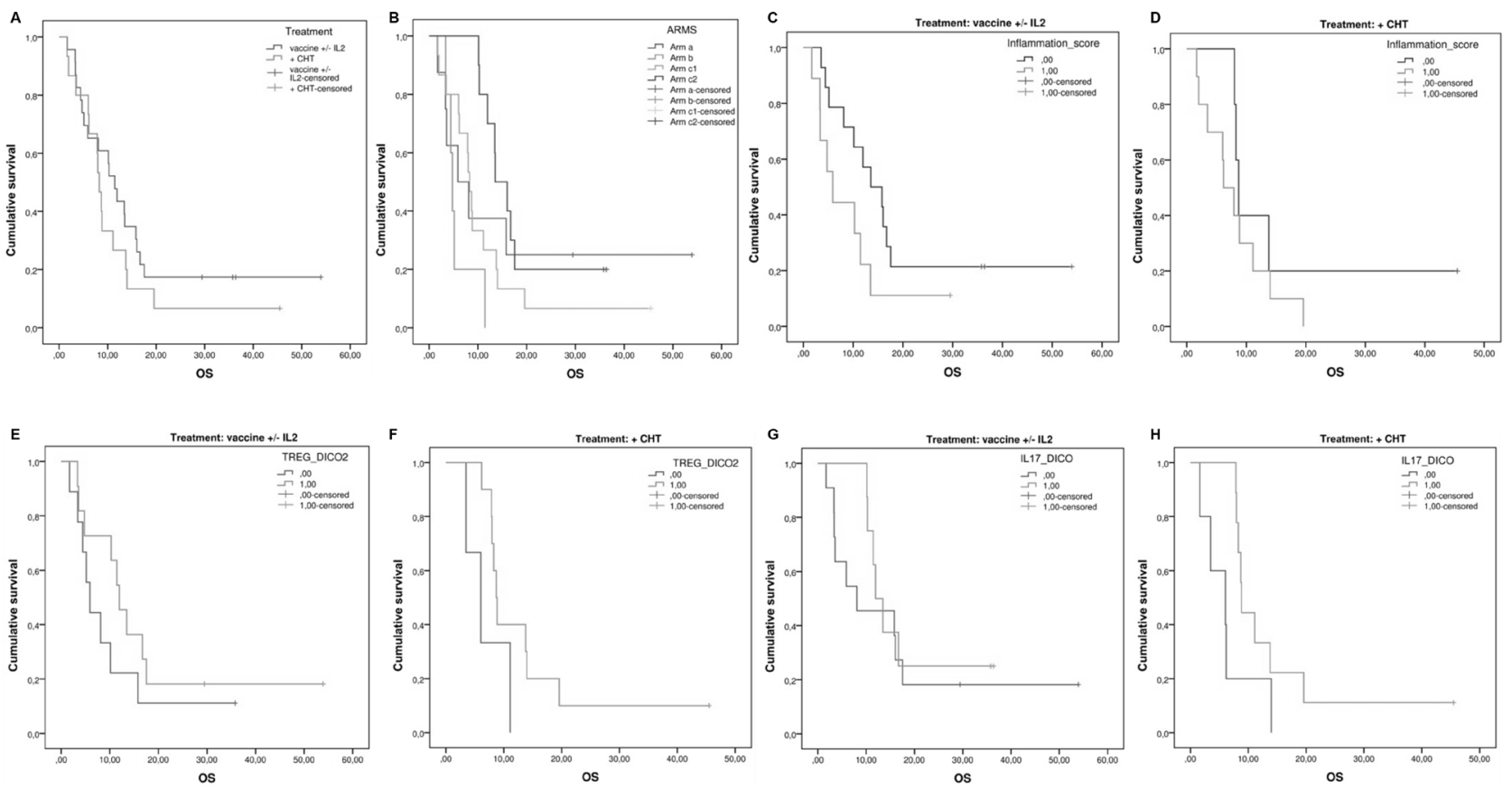

Figure 2: Evaluation of predictive markers in patients who received TSPP \pm cytokines and TSPP + GOLFIG chemoimmunotherapy. (A) Overall survival in mCRC patients who received TSPP \pm cytokines (Arm A + B) vs those who received TSPP + GOLFIG regimen (Arm C/DL + Arm C/DL1-3). (B) Overall survival in mCRC patients enrolled in the different treatment arms (Arm A vs $\mathrm{B}$ vs C/DL0 vs C/DL1-3). (C) Influence of the inflammation score (NLR, PCR, LDH) on the survival of mCRC patients who received TSPP \pm cytokines (Arm A and B). (D) Influence of the inflammation score (NLR, PCR, LDH) on the survival of mCRC patients who received TSPP + GOLFIG regimen (Arm C/DL0-3). (E) Influence of peripheral $\mathrm{T}_{\text {reg }}$ s' baseline levels on the survival of mCRC patients who received $\mathrm{TSPP} \pm$ cytokines (Arm A and B). (F) Influence of peripheral $\mathrm{T}_{\mathrm{reg}} \mathrm{s}$ ' baseline levels on the survival of mCRC patients who received TSPP + GOLFIG regimen (Arm C/DL0-3). (G) Influence of IL17/A baseline levels on the survival of mCRC patients who received TSPP \pm cytokines (Arm A and B) (H) Influence of IL17/A baseline levels on the survival of mCRC patients who received TSPP + GOLFIG regimen (Arm C/DL0-3). Asterisk (*) represents statistical significance between the arms $(P<0.05)$. 


\begin{tabular}{|c|c|c|c|c|c|}
\hline Comparative marker & Cut-off value & $\begin{array}{c}\text { Number } \\
\text { of } \\
\text { patients }\end{array}$ & Months \pm SD & Endpoint & $P$ value \\
\hline \multirow[t]{2}{*}{$\begin{array}{l}\text { NLR (neutrophil to } \\
\text { lymphocytes ratio) }\end{array}$} & $\begin{array}{l}\leq \text { median value } \\
>\text { median value }\end{array}$ & $\begin{array}{l}20 \\
20\end{array}$ & $\begin{array}{c}11,10 \pm 3,18 \\
3,80 \pm 0,59\end{array}$ & PFS & 0.010 \\
\hline & $\begin{array}{l}\leq \text { median value } \\
>\text { median value }\end{array}$ & $\begin{array}{l}20 \\
20\end{array}$ & $\begin{array}{c}19,01 \pm 3,97 \\
7,40 \pm 1,04\end{array}$ & OS & 0.011 \\
\hline \multirow[t]{2}{*}{ NeutrophilFBV } & $\begin{array}{l}\leq 1 \\
>1\end{array}$ & $\begin{array}{l}25 \\
14\end{array}$ & $\begin{array}{c}10,16 \pm 2,57 \\
3,07 \pm 0,67\end{array}$ & PFS & 0.003 \\
\hline & $\begin{array}{l}\leq 1 \\
>1\end{array}$ & $\begin{array}{l}25 \\
14\end{array}$ & $\begin{array}{c}18,51 \pm 3,38 \\
5,85 \pm 1,29\end{array}$ & OS & 0.001 \\
\hline \multirow[t]{2}{*}{ CRP } & $\begin{array}{l}\leq \text { median value } \\
>\text { median value }\end{array}$ & $\begin{array}{l}20 \\
20\end{array}$ & $\begin{array}{c}11,25 \pm 3,17 \\
3,65 \pm 0,54\end{array}$ & PFS & 0.005 \\
\hline & $\begin{array}{l}\leq \text { median value } \\
>\text { median value }\end{array}$ & $\begin{array}{l}20 \\
20\end{array}$ & $\begin{array}{c}19,75 \pm 4,10 \\
7,40 \pm 1,48\end{array}$ & OS & 0.002 \\
\hline \multirow[t]{2}{*}{ CRP FBV } & $\begin{array}{l}\leq 1 \\
>1\end{array}$ & $\begin{array}{l}6 \\
6\end{array}$ & $\begin{array}{c}5,33 \pm 1,05 \\
12,83 \pm 3,59\end{array}$ & PFS & 0.019 \\
\hline & $\begin{array}{l}\leq 1 \\
>1\end{array}$ & $\begin{array}{l}6 \\
6\end{array}$ & $\begin{array}{l}10,66 \pm 2,00 \\
22,04 \pm 3,81\end{array}$ & OS & 0.027 \\
\hline \multirow[t]{2}{*}{ ESR } & $\begin{array}{l}\leq \text { median value } \\
>\text { median value }\end{array}$ & $\begin{array}{l}19 \\
18\end{array}$ & $\begin{array}{c}10,15 \pm 3,14 \\
5,27 \pm 1,69\end{array}$ & PFS & 0.090 \\
\hline & $\begin{array}{l}\leq \text { median value } \\
>\text { median value }\end{array}$ & $\begin{array}{l}19 \\
18\end{array}$ & $\begin{array}{c}18,92 \pm 3,69 \\
7,52 \pm 1,97\end{array}$ & OS & 0.002 \\
\hline \multirow[t]{2}{*}{ LDH/LDHNR } & $\begin{array}{l}\leq \text { median value } \\
>\text { median value }\end{array}$ & $\begin{array}{l}19 \\
19\end{array}$ & $\begin{array}{c}10,84 \pm 3,36 \\
4,42 \pm 0,80\end{array}$ & PFS & 0.106 \\
\hline & $\begin{array}{l}\leq \text { median value } \\
>\text { median value }\end{array}$ & $\begin{array}{l}19 \\
19\end{array}$ & $\begin{array}{c}19,64 \pm 3,88 \\
6,60 \pm 0,84\end{array}$ & OS & 0.001 \\
\hline ENA & $\begin{array}{l}\leq \text { median value } \\
>\text { median value }\end{array}$ & $\begin{array}{l}20 \\
17\end{array}$ & $\begin{array}{c}18,47 \pm 3,78 \\
8,58 \pm 2,11\end{array}$ & OS & 0.011 \\
\hline cANCA & $\begin{array}{l}\leq \text { median value } \\
>\text { median value }\end{array}$ & $\begin{array}{l}18 \\
18\end{array}$ & $\begin{array}{c}16,66 \pm 3,72 \\
12,30 \pm 2,99\end{array}$ & OS & 0.510 \\
\hline $\mathrm{pANCA}$ & $\begin{array}{l}\leq \text { median value } \\
>\text { median value }\end{array}$ & $\begin{array}{l}16 \\
18\end{array}$ & $\begin{array}{l}18,37 \pm 4,05 \\
11,57 \pm 2,89\end{array}$ & OS & 0.17 \\
\hline $\begin{array}{l}\mathrm{pANCA} \\
\text { FBV }\end{array}$ & $\begin{array}{l}\leq 1 \\
>1\end{array}$ & $\begin{array}{c}8 \\
13\end{array}$ & $\begin{array}{c}6,12 \pm 1,67 \\
16,76 \pm 4,22\end{array}$ & OS & 0.039 \\
\hline IFN y & $\begin{array}{l}\leq \text { median value } \\
>\text { median value }\end{array}$ & $\begin{array}{l}16 \\
16\end{array}$ & $\begin{array}{l}11,68 \pm 3,07 \\
18,31 \pm 3,81\end{array}$ & $\mathrm{OS}$ & 0.154 \\
\hline IL12p70 & $\begin{array}{l}\leq \text { median value } \\
>\text { median value }\end{array}$ & $\begin{array}{l}17 \\
17\end{array}$ & $\begin{array}{l}18,05 \pm 4,24 \\
10,91 \pm 1,98\end{array}$ & OS & 0.250 \\
\hline IL17 & $\begin{array}{l}\leq \text { median value } \\
>\text { median value }\end{array}$ & $\begin{array}{l}18 \\
18\end{array}$ & $\begin{array}{l}10,16 \pm 2,57 \\
17,83 \pm 3,36\end{array}$ & OS & 0.056 \\
\hline IL10 & $\begin{array}{l}\leq \text { median value } \\
>\text { median value }\end{array}$ & $\begin{array}{l}16 \\
16\end{array}$ & $\begin{array}{l}15,19 \pm 4,12 \\
11,77 \pm 1,92\end{array}$ & OS & 0.747 \\
\hline IL4 & $\begin{array}{l}\leq \text { median value } \\
>\text { median value }\end{array}$ & $\begin{array}{l}18 \\
16\end{array}$ & $\begin{array}{l}10.33 \pm 2.80 \\
18.99 \pm 3,55\end{array}$ & OS & 0.028 \\
\hline
\end{tabular}




\begin{tabular}{|c|c|c|c|c|c|}
\hline $\mathrm{T}_{\mathrm{EM}}$ & $\begin{array}{l}\leq \text { median value } \\
>\text { median value }\end{array}$ & $\begin{array}{l}19 \\
17\end{array}$ & $\begin{array}{l}13,25 \pm 2,30 \\
15,86 \pm 4,46\end{array}$ & OS & 0.887 \\
\hline $\mathrm{T}_{\mathrm{CM}}$ & $\begin{array}{l}\leq \text { median value } \\
>\text { median value }\end{array}$ & $\begin{array}{l}18 \\
18\end{array}$ & $\begin{array}{l}12,05 \pm 3,42 \\
15,64 \pm 2,88\end{array}$ & OS & 0.149 \\
\hline $\mathrm{T}_{\mathrm{REG}}$ & $\begin{array}{l}\leq \text { median value } \\
>\text { median value }\end{array}$ & $\begin{array}{l}17 \\
19\end{array}$ & $\begin{array}{l}13,94 \pm 3,77 \\
14,34 \pm 2,84\end{array}$ & OS & 0.833 \\
\hline
\end{tabular}

Legend: PFS, progression-free survival; OS, overall survival; NeutrophilFBV, Neutrophil fractional blood volume; CRP, C-reactive protein; ESR, erythrocyte-sedimentation rate; LDH/LDHNR, Lactate Dehydrogenase/Lactate Dehydrogenase Normal Range; ENA, anti-extractable nuclear antigen; cANCA, anti-neutrophil cytoplasmic antibodies/ anti-myeloperoxidase; pANCA, anti-neutrophil cytoplasmic antibodies/anti-proteinase-3; IFN y, Interferon gamma; IL, interleukin, $\mathrm{T}_{\mathrm{EM}}$, effector/ memory $\mathrm{T}$ lymphocytes; $\mathrm{T}_{\mathrm{CM}}$, central memory $\mathrm{T}$ lymphocytes; TREG, regulatory $\mathrm{T}$ lymphocytes.

Table 5: Inflammatory predictive markers/k-ras mutational status correlation with clinical outcome of the patients

\begin{tabular}{|c|c|c|c|c|c|c|}
\hline Subgroup & $\begin{array}{c}\text { Comparative } \\
\text { marker }\end{array}$ & Cut-off value & $\begin{array}{c}\text { Number of } \\
\text { patients }\end{array}$ & Months \pm SD & Endpoint & $P$ value \\
\hline \multirow[t]{6}{*}{ k-ras/wt } & Neutrophil Count & $\begin{array}{l}\leq \text { median value } \\
>\text { median value }\end{array}$ & $\begin{array}{c}10 \\
9\end{array}$ & $\begin{array}{l}24,11 \pm 6,21 \\
10,22 \pm 2,72\end{array}$ & OS & 0.050 \\
\hline & NLR & $\begin{array}{l}\leq \text { median value } \\
>\text { median value }\end{array}$ & $\begin{array}{c}12 \\
8\end{array}$ & $\begin{array}{c}23,06 \pm 5,37 \\
8,25 \pm 1,57\end{array}$ & OS & 0.020 \\
\hline & CRP & $\begin{array}{l}\leq \text { median value } \\
>\text { median value }\end{array}$ & $\begin{array}{c}11 \\
9\end{array}$ & $\begin{array}{c}23,26 \pm 5,62 \\
9,44 \pm 2,65\end{array}$ & OS & 0.023 \\
\hline & ENA & $\begin{array}{l}\leq \text { median value } \\
>\text { median value }\end{array}$ & $\begin{array}{c}9 \\
10\end{array}$ & $\begin{array}{l}24,46 \pm 5,55 \\
10,90 \pm 3,36\end{array}$ & OS & 0.029 \\
\hline & IL12 p70 & $\begin{array}{l}\leq \text { median value } \\
>\text { median value }\end{array}$ & $\begin{array}{c}12 \\
7\end{array}$ & $\begin{array}{c}22,58 \pm 5,45 \\
9,71 \pm 1,10\end{array}$ & OS & 0.034 \\
\hline & IL17 & $\begin{array}{l}\leq \text { median value } \\
>\text { median value }\end{array}$ & $\begin{array}{c}11 \\
8\end{array}$ & $\begin{array}{l}14,54 \pm 4,03 \\
21,50 \pm 5,35\end{array}$ & OS & 0.379 \\
\hline \multirow[t]{6}{*}{ k-ras/mut } & Neutrophil Count & $\begin{array}{l}\leq \text { median value } \\
>\text { median value }\end{array}$ & $\begin{array}{l}9 \\
9\end{array}$ & $\begin{array}{c}7,77 \pm 2,29 \\
10,00 \pm 3,04\end{array}$ & OS & 0.567 \\
\hline & NLR & $\begin{array}{l}\leq \text { median value } \\
>\text { median value }\end{array}$ & $\begin{array}{c}8 \\
10\end{array}$ & $\begin{array}{c}10,75 \pm 3,48 \\
7,10 \pm 1,70\end{array}$ & OS & 0.411 \\
\hline & CRP & $\begin{array}{l}\leq \text { median value } \\
>\text { median value }\end{array}$ & $\begin{array}{l}9 \\
9\end{array}$ & $\begin{array}{c}12,55 \pm 3,45 \\
5,77 \pm 1,88\end{array}$ & OS & 0.123 \\
\hline & ENA & $\begin{array}{l}\leq \text { median value } \\
>\text { median value }\end{array}$ & $\begin{array}{c}11 \\
7\end{array}$ & $\begin{array}{c}11,48 \pm 3,06 \\
5,28 \pm 0,91\end{array}$ & OS & 0.055 \\
\hline & IL12 p70 & $\begin{array}{l}\leq \text { median value } \\
>\text { median value }\end{array}$ & $\begin{array}{c}5 \\
10\end{array}$ & $\begin{array}{c}7,60 \pm 3,01 \\
11,75 \pm 3,26\end{array}$ & OS & 0.247 \\
\hline & IL17 & $\begin{array}{l}\leq \text { median value } \\
>\text { median value }\end{array}$ & $\begin{array}{l}6 \\
9\end{array}$ & $\begin{array}{c}4,50 \pm 2,46 \\
14,27 \pm 3,10\end{array}$ & OS & 0.010 \\
\hline
\end{tabular}

Legend: OS, overall survival; NLR, Neutrophil/lymphocyte ratio; CRP, C-reactive protein; ENA, anti-extractable nuclear antigen; IFN $\gamma$, Interferon gamma; IL, interleukin.

Concerning the immune-biological monitoring, the best outcome in patients with lower systemic inflammatory baseline profile (neutrophil counts, NLR, CRP,ESR, LDH/ LDHNV, and ENA) and higher baseline levels of IL-4, which may promote occurrence of auto-antibody-driven autoimmunity, was found $[22,23]$. The best outcome was also detected in vaccines with increase in pANCA, an autoantibodies, whose presence is suggestive of autoimmunity 
and micro-vascular damage [24]. A prolonged survival was found in patients who showed a progressive rise in peripheral $\mathrm{CD} 3 \mathrm{CD} 56^{\mathrm{dim}} \mathrm{CD} 16^{\text {bright }} \mathrm{NKs}$, a lymphocyte subset, which together with an antigen independent antitumor activity also holds the ability to promote an antigen specific $\mathrm{T}$ cell response stimulating the functional activity of peripheral DCs [25]. In our study, other parameters, including cytokines' (TNF $\alpha$, IL17/A, IL12/p70, IL10) and cell subsets' $\left(\mathrm{CD}^{+} \mathrm{CD}^{+}, \mathrm{CD}^{+} \mathrm{CD}^{+}, \mathrm{T}_{\mathrm{cm}} \mathrm{s}, \mathrm{T}_{\mathrm{em}} \mathrm{s}\right.$, $\mathrm{T}_{\text {reg }} \mathrm{s}$, MDSCs) in peripheral blood, did not correlated with either PFS or OS on the whole population. Since experimental evidence suggests that alterations on k-ras pathway in CRC cells may have dramatic consequences within tumor micro-environment, involving inflammation, angiogenesis, and immune-response, we examined the predictive values of our markers in the two subsets of patients with k-ras/wt and k-ras/mut. The results showed that the inflammatory markers have a strict correlation with survival only in the k-ras/wt group, losing any statistical significance in patients with k-ras/mut. Interestingly, in the latter group of patients, the outcome was directly correlated to the baseline levels of IL17/A, an inflammatory cytokine able to amplify and empower the cytotoxic effects of preexisting CTLs in CRC tumor sites [26]. These 2 groups of patients did not show significant difference prior TSPP treatment with the exception of a much lower tumor infiltration by CD $15^{+}$inflammatory cells in the k-ras/mut group. This finding is suggestive of a different cancer associate-inflammatory profile within the tumor tissue with a different sensitivity to both cytotoxic stimula and cytotoxic effectors. In line with these findings, the 2 groups of patients presented a different immune-biological response to TSPP vaccination. In fact, patients with k-ras/ mut failed to induce auto-antibodies, such as cANCA and ENA, in response to TSPP vaccination, while their treatment was associated to increase in peripheral levels of IFN $\gamma$, IL17/A, and $\mathrm{T}_{\text {reg }} \mathrm{s}$. In this context, IFN $\gamma$ is an inflammatory cytokine, which is able to enhance the expression of PDL-1 on CRC cells and immune-cells in the tumor sites. This event potentially leads to empowerment of the PD-1/PDL1 immune-check point activity and neutralization of activated CTLs in the tumor. Additionally, and it is also known that IL17/A together with IFN $\gamma$ promotes the switch of inactive $\mathrm{T}_{\text {reg }} \mathrm{s}$ to highly suppressive $\mathrm{T}_{\text {reg }} \mathrm{s}$ [27], which in turn, could affect the primary $\mathrm{T}$ cell response to TSPP vaccine of these patients. On the other hand, the results of other studies suggest that IL17/A production may also empower the cytotoxic activity of preexisting effector CTLs in the tumor site [28].This finding could also partially explain the predictive value of IL17/A baseline levels only in patients with k-ras/mut and in patients who receive TSPP vaccination and GOLFIG chemo-immunotherapy (Arm-C/DL0-3).

A number of studies have already, highlighted the detrimental effects of systemic inflammation in patients with different malignancies undergoing immunebiological treatments [29-35]. Several studies, also suggest the existence of a strong link among angiogenesis, pro-inflammatory context and immune-editing within the tumor environment, which in turn could affect the responsiveness of the malignant cells to pro-apoptotic signals and immune-response [36].

These detrimental effects of cancer-associate inflammation are similar to those induced in the tumor
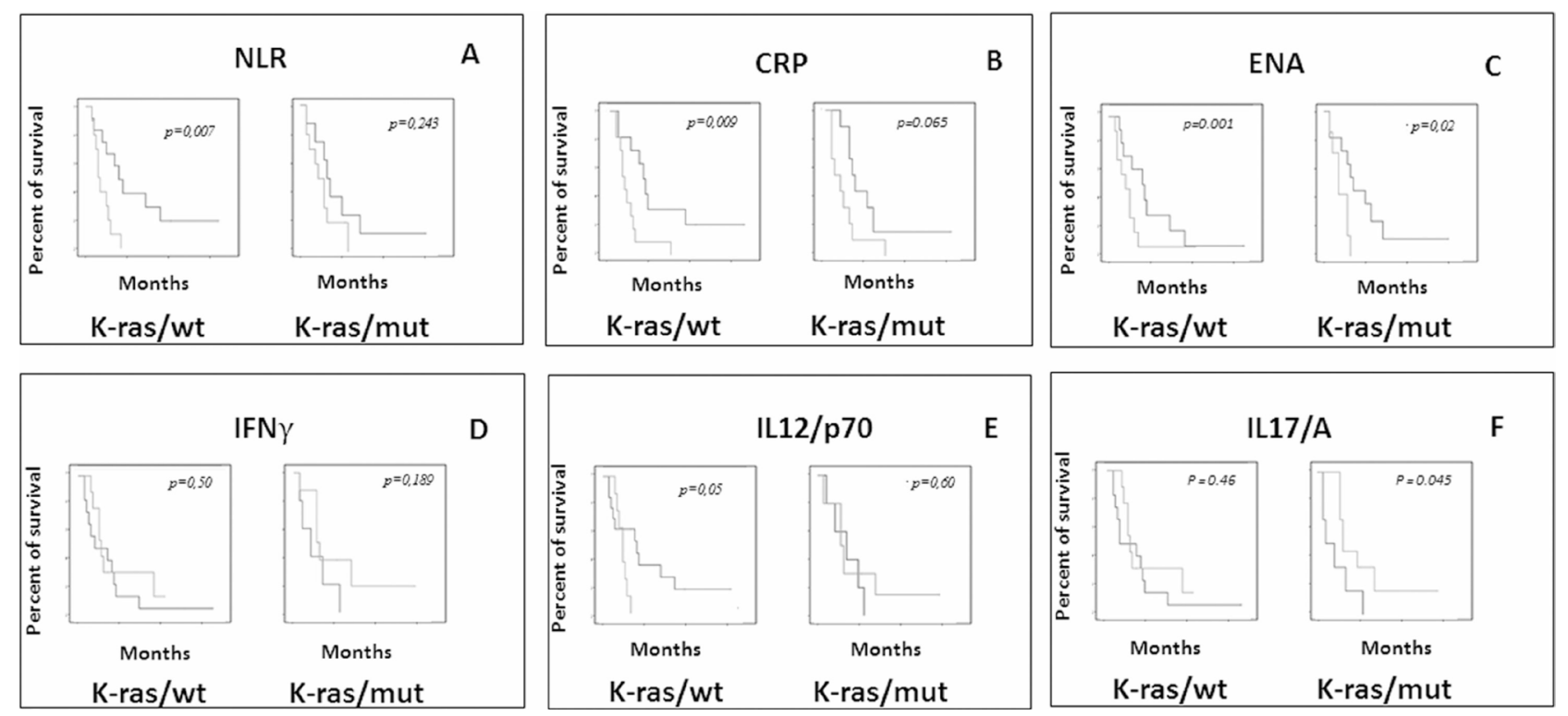

Figure 3: Evaluation of predictive markers in mCRC patients with k-ras/wt and k-ras/mut who received TSPP vaccine. Different influence of baseline levels of NLR (A), CRP (B), ENA (C), IFN $\gamma(\mathbf{D})$, IL12/p70 (E) and IL17/A (F) on k-ras wt and k-ras mut patients treated with TSPP vaccine. Overall survival was compared between the two groups of patients with baseline levels $<$ and $\geq$ the median value of each specific parameter. Asterisk $\left(^{*}\right)$ represents statistical significance between the arms $(P<0.05)$. 
microenvironment by the presence of a malfunctioning k-ras pathway. In this context, it has been shown that the expression of activating $\mathrm{k}$-ras mutation in CRC cells promotes the release pro-angiogenic factors, proinflammatory cytokines, and chemokines, that in turn, make the tumor micro-environment able to protect the tumor by multiple pro-apoptotic stimula (cytotoxic drugs, anti-EGFR mAbs, CTLs, etc.) [37-43]. This hypothesis is in line with the finding that patients with $\mathrm{k}$-ras/wt and k-ras/mut present a different immune-biological response to TSPP vaccination with a worse outcome.

On these bases, we can conclude that the outcome of mCRC patients vaccinated with TSPP may be greatly hampered by their systemic inflammatory profile and by an altered k-ras pathway. This finding deserves further studies and must be taken into account in the design of future studies aimed to evaluate the antitumor activity of immunological strategies like TSPP vaccine in $\mathrm{mCRC}$ patients.

\section{PATIENTS AND METHODS}

The TSPP/VAC-1 is a phase Ib trial program designed to test in advanced cancer patients, the toxicity and immunological activity of TSPP in different therapeutic conditions,. The protocol consisted of three parallel and independent arms where TSPP vaccination was administered alone (arm-A) and in combination with the immune-adjuvant IG-1 regimen (arm-B) and in combination with the chemo-immunotherapy GOLFIG regimen (arm-C). The latter arm was reserved to $\mathrm{mCRC}$ patients and evaluated the effects of peptide vaccination, administered concomitantly (DL1-3) or after (DL0) 10/12 GOLFIG courses.

\section{Ethical considerations and study design}

The study was designed according to good clinical practice (GCP) recommendations. It was authorized by the Italian National Institute of Health (Istituto Superiore di Sanità), the Italian Ministry of Health, and approved by the University of Siena Ethical Committee Board (equivalent to Human Subject Committee of Investigational Review Board). The study registered with the TSPP/VAC-1 code (Eudract: \# 2009-016897-33)was planned as a dose escalation trial, in three parallel and independent arms (A, $\mathrm{B}$ and $\mathrm{C}$ ). TSPP dose-escalation was planned according to the Fibonacci's series. The first cohort of patients received $100 \mu \mathrm{g}$ of peptide (DL1), the second, $200 \mu \mathrm{g}$ (DL2), and the third $300 \mu \mathrm{g}$ (DL3), every 21 days. New patients could be enrolled in higher dose level cohorts, only if no Grade IV event was demonstrated in patients treated with lower doses. Patients of arm A (8) received vaccine peptide alone, those of arm B (4) received TSPP and sc. GM-CSF (Sargramostim / Leukine ${ }^{\circledR}$, Berlex, USA) $(50 \mu \mathrm{g}$ days 1-5) and sc. Aldesleukine/Proleukin ${ }^{\circledR}$, Novartis,
Switzerland (0.5 MIU bi-daily, days 6-15) according to the previously described IG-1 schedule [7]. Patients of arm C/DL1-3 (17) received peptide vaccination seven days after the beginning of the chemo-immunotherapy cycle with gemcitabine $1 \mathrm{~g} / \mathrm{sqm}$ on the day 1 , oxaliplatin $85 \mathrm{mg} / \mathrm{sqm}$ on the day 2, Levofolinic acid $100 \mathrm{mg} / \mathrm{sqm}$ on the days 1 and 2, bolus 5'-FU $400 \mathrm{mg} / \mathrm{sqm}$ on days 1 and 2 and infusional $5^{\prime}$-FU $800 \mathrm{mg} / \mathrm{sqm}$ on days 1 and 2 , every 15 days according to the previously described GOLFIG [9-11]. These patients also received sc. GM-CSF (50 $\mu \mathrm{g}$ days $3-7)$ and sc. IL-2 (0.5 MIU bi-daily on days 8-14 and 17-29). In particular, 17 patients of the latter group, received sc. TSPP vaccination at escalating dosage [3 patients entered the DL-1; 3, the DL-2; 11, the DL-3 cohort] on biweekly bases, starting one week after each chemotherapy cycle (concomitant treatment). Other12 patients received GOLFIG chemo-immunotherapy alone (DL0) for 10/12 courses and then maintenance therapy with the same schedule adopted for arm B (TSPP + IG1).

Two patients of the DL0 group did not receive TSPP vaccination, due to early disease progression and decline in performance status, thus they were excluded by the statistical analysis. The remaining 10 patients entering the maintenance therapy group ( $\mathrm{DLO}_{\text {mant }}$ ), received TSPP vaccination every 3 weeks $(300 \mu \mathrm{g}$ on the day 1$)$, sc.GMCSF (50 $\mu \mathrm{g}$ at day, days $1-5$ every 3 weeks), and sc.rIL2 (0.5 MIU twice at day, days 6-15 every 3 weeks) $[5,6]$.

\section{TSPP Vaccine}

TSPP (YMIAHITGLFLDSLGFSTTLGDAHIYL) [4] was synthesized and characterized by good manufacturing practice (GMP) procedures by the American Peptide Ltd (Rockville, MD,USA). The aseptic vial filling process was performed by the Pharmacy of the Azienda Ospedaliera Universitaria Senese, which also performed the stability study, endotoxin evaluation and chemical related toxicity analysis of the product. TSPP was dissolved in DMSO and the exact peptide dose $(100,200$ or $300 \mu \mathrm{g})$ was diluted with PBS in a volume of $250 \mu \mathrm{l}$, and then 1:2 diluted with Montanide ISA 720 VG ST (Seppic, Milan, Italy) as adjuvant. The final volume of the vaccine was $500 \mu \mathrm{l} /$ dose.

\section{Patients' population and study endpoints}

Our analysis was performed on a sample of 41 mCRC patients. The primary endpoints of the study were the identification of the maximal tolerated dose (MTD) and the most effective biological dose (MEBD) of TSPP peptide, by evaluating the frequency of adverse events per dose level and predefined immune-biological events in the three cohorts of patients. Evidence of anti-tumor activity was a secondary endpoint. The inclusion criteria were: written informed consent concerning treatment risk and biological monitoring, histological diagnosis of 
malignant disease, at least two previous chemotherapy lines for advanced disease, measurable disease (according to WHO tumor response criteria), ECOG performance status $\leq 1$, normal renal and hepatic functions, white blood cell count $\geq 2,500 / \mathrm{mm}^{3}$, hemoglobin levels $\geq 9 \mathrm{~g} / \mathrm{dl}$, platelet cell count $\geq 100,000 / \mathrm{mm}^{3}$, and normal heart function. The exclusion criteria were: any major organ failure, central nervous system involvement, second malignancies, active infectious disease, major inflammatory and autoimmune rheumatic diseases, and acquired immune-suppression. Treatment allocation was not masked. Standard clinical and laboratory evaluation (clinical history, physical examination, blood count and chemistry, serum dosage of C-reactive protein (CRP), erythrocyte-sedimentation rate $(\mathrm{ESR})$, lactate dehydrogenase $(\mathrm{LDH})$, rheumatoid factor, carcinoembryonic antigen (CEA) and CA19.9 assays, chest x-rays and ultrasound abdominal scans, were performed at baseline and repeated every six weeks. Patients' sera were tested for antinuclear antibodies (ANA) by IFA, (starting dilution 1:160) (SSA HEp2000, ImmunoConcepts); EliASymphony screening (Thermo Fisher Scientific); further ELiA tests were performed for single ANA specificities. ANCA, p-ANCA, and C-ANCA were measured by indirect immunofluorescence using INOVA substrate, while ENA was tested on Phadia250 instrument. Contrast CT scans were scheduled every three months. Patients enrolled in the arm C/DL1-3 received combined TSPP/GOLFIG treatment for a maximal of 12 cycles, then those who did not progress, received TSPP vaccination every 21 days at the dosage of $300 \mu \mathrm{g}$ until disease progression, occurrence of unacceptable toxicity, clinical judgment, or withdrawal of consent. Any further treatment decision after disease progression was left to the physician in charge. Adverse events, toxicity and treatment response were evaluated according to WHO classification.

\section{ELISA assays and multiplex analysis}

Serum levels of Interferon(IFN)- $\mathrm{\gamma}$, Tumor necrosis factor (TNF)- $\alpha$, IL10, IL4, IL12/A, IL10 and IL17/A cytokines were measured using Bio-Plex human cytokine multiplex kits (Bio-Rad Inc., Hercules, CA). Briefly, a standard curve was created via dilution of premixed standards to $50,000 \mathrm{pg} / \mathrm{ml}$, followed by serial dilution to 8 concentrations ranging from 32,000 to $1.95 \mathrm{pg} / \mathrm{ml}$. The assay was performed in the 96-well filtration plate supplied with the Bio-Plex kit. Premixed beads coated with target antibodies $(50 \mu \mathrm{l})$ were added to each well, and then washed twice with Bio-Plex wash buffer. Premixed standards or undiluted samples $(50 \mu \mathrm{l})$ were then added to the wells, followed by shaking at $1,100 \mathrm{rpm}$ for $30 \mathrm{sec}$ and incubation for $30 \mathrm{~min}$ with shaking at $300 \mathrm{rpm}$ at room temperature. Wells were then washed 3 times with Bio-Plex wash buffer, and $25 \mu 1$ of the premixed detection antibodies was added to the wells. This was followed by shaking at 1,100 rpm for $30 \mathrm{sec}$ and incubation for $30 \mathrm{~min}$ with shaking at $300 \mathrm{rpm}$ at room temperature. Wells were again washed 3 times with Bio-Plex wash buffer, and 50 $\mu \mathrm{l}$ of streptavidin-PE was added to the wells. This was incubated for $10 \mathrm{~min}$ with shaking at $300 \mathrm{rpm}$. Wells were washed 3 times with Bio-Plex wash buffer, and the beads were resuspended in $125 \mu \mathrm{l}$ Bio-Plex assay buffer. The samples were then read using the Bio-Plex suspension array system. The fluorescence intensity of the beads was measured by using the Bio-Plex array reader. Bio-Plex Manager software with five-parametric-curve fitting was used for data analysis.

\section{Fluorescence-activated cell sorting analysis of patient peripheral blood mononuclear cells (PBMC)}

The patients' PBMCs were purified by FicollHypaque (Celbio S.P.A., Italy) gradient separation of buffy coats of heparinized blood samples and analyzed by Fluorescence-activated cell sorting (FACS) analysis, as described in previous studies $[5,6]$.

PBMC were stained with different pools of labeled monoclonal antibodies (mAbs) (CD4V450, CD45RAPE, CD62LFITC, CCR7PE-Cy7, Pharmingen;CD8PerCPCy 5.5, CD45ROAPC, CD3FITC, CD19FITC, CD14FITC, CD11cAPC, CD16PE, Rat IgG2aFITC, Mouse IgG1, Becton Dickinson, Italy; CD56 APC, Mouse IgG2a APC Immunotools, DE; CD15 PE ABCam, UK; CD25 PE, FoxP3 FITC, eBioscence, UK) and examined by a FACScalibur BD instrument. The fluorescent-minus-one and isotype control were included in each experiment in order to appropriately set the gates. Ki67 positive cells and $\mathrm{T}_{\text {reg }} \mathrm{s}$ were analyzed after intracellular immune-staining according to the manufacturer's protocol (eBioscience). Cytofluorimetric analysis was carried out by using the Flow $\mathrm{Jo}^{\circledR}$ software. The mean fluorescence intensity (MFI) and percent of positive expression (\%) of each marker were measured. Results were expressed as fold induction relative to baseline indicated as 1 .

\section{Immunoistochemistry}

immunohistochemistry was performed for TS expression in primary tumors and tumor infiltrating $\mathrm{T}$ cells expressing FoxP3 (Treg), CCR7 (Tcm/em), CD4, or CD8 and inflammatory cells expressing CD15. This analysis was carried out in the primary tumor of 41 mCRC patients who received TSPP vaccine, whose 22 with k-ras wt and 19 with mutated k-ras. In brief, sections were deparaffinized and peroxidase activity blocked. Antigen retrieval was performed with $1 \mathrm{~m} \mu$ EDTA $\mathrm{pH}$ 8.0, following which endogenous biotin was blocked by use of a commercial kit (Vector Laboratories, Inc., Burlingame, CA, USA) before incubation in $20 \%$ swine serum for $30 \mathrm{~min}$. The primary antibody (\#9718; Cell Signalling Technology, Inc., Danvers, MA, USA) was 
added at a concentration of $1: 100$ and sections incubated overnight at $4^{\circ} \mathrm{C}$. Sections were then incubated for 90 min with a biotin-conjugated secondary antibody (Dako UK Ltd, Ely, UK) and for $45 \mathrm{~min}$ with streptavidin biotin-peroxidase conjugate (Vector Laboratories, Inc.). 3,3'-diaminobenzidine tetrahydrochloride (DAB; Vector Laboratories, Inc.) was used as the chromogen. The numbers of positive stained cells in 15 separate highpower fields $(\mathrm{HPF}$; magnification $\times 20$ ) were counted in a blinded manner. Results are expressed as number of positive cells per HPF.

\section{Statistical analysis}

Survival analysis and correlations between patient's baseline characteristics and toxicity were evaluated by Kaplan Meier curves and Wilcoxon test statistic in the univariate analysis. All potential prognostic factors were transformed into categorical variables. Results were expressed as mean \pm standard deviation (SD) of three determinations made in three different experiments, and analysed by the 2-tail Student's $t$-test. A $p$-values $\leq 0.05$ were considered statistically significant. Variables with a $p$-value lower than 0.10 were used to construct the predictive models. These variables were entered into a multivariate analysis model according to Cox proportional hazard model to analyse the role of confounding factors, modelling the relationship among a set of one or more covariates and the hazard rate. The most significant variables were entered in the model through a step-wise method. Time variable contains the length of time during which a subject has been observed, representing a failure/ censor time. Overall survival (OS) was measured from the beginning of the treatment to the day of death from any cause. Progression-free survival (PFS) was calculated from the the beginning of the treatment to the day of local or distant recurrence or death from any cause. PFS and OS in particular, were correlated with selected immune-biological parameters with potential prognostic values. In order to perform the screening of these markers we evaluated the quantitative baseline values by dividing the patients in two groups according to the specific median value of each marker prior and after treatment and median post-treatment fold change to baseline values. Univariate analyses were conducted with the log-rank test and multivariate analyses with the Cox proportional hazard model. All survival data were analysed by using the SPSS software (version 23) and GraphPadInstat 3.2. statistical packages.

\section{Abbreviations}

ENA: anti-extractable nuclear antigen; cANCA: anti-myeloperoxidase; pANCA: anti-neutrophil cytoplasmic antibodies/anti-proteinase-3; ANA: Antinuclear anti-bodies; CEA: carcinoembryonic antigen; CRP: C-reactive protein; DC: dendritic cells; ECOG: eastern cooperative oncology group performance status; ESR: erythrocyte-sedimentation rate; FACS: fluorescenceactivated cell sorting; GM-CSF: granulocyte macrophagecolony-stimulating-factor; LDH: lactate dehydrogenase; IFN-y: Interferon; IL-2: interleukin-2; mCRC: metastatic colorectal cancer; PBMCs: peripheral blood mononuclear cells; TNF: Thymidylate-synthase poly-epitope peptide TSPP: Tumor necrosis factor.

\section{Author contributions}

(I) Conception and design: Pierpaolo Pastina, Pierpaolo Correale; Cirino Botta, Pierfrancesco Tassone, Pierosandro Tagliaferrri; (II) Administrative support: Michele Caraglia, Pierpaolo Correale; (III) Provision of study materials or patients: All authors; (IV) Collection and assembly of data: All authors; (V) Data analysis and interpretation: All authors; (VI) Manuscript writing: All authors; (VII) Final approval of manuscript: All authors.

\section{ACKNOWLEDGMENTS}

A special thanks to all patients and their families who enthusiastically participated in the study.

\section{CONFLICTS OF INTEREST}

All the authors declare no conflicts of interest

\section{FUNDING}

This study was supported by the Italian Ministry of Health "Ricercafinalizzata2010 "RF-2010-2313550 and the "Associazione culturale Federico II", Siena, and partially by the Innovative Immunotherapeutic Treatments of Human Cancer, Multi Unit Regional No. 16695 (cofinanced by AIRC and the CARICAL foundation), 2015/18 (PI: PT).

\section{REFERENCES}

1. Correale P, Sabatino M, Cusi MG, Micheli L, Nencini C, Pozzessere D, Petrioli R, Aquino A, De Vecchis L, Turriziani M, Prete SP, Sanguedolce R, Rausa L, et al. In vitro generation of cytotoxic T lymphocytes against HLAA2.1-restricted peptides derived from human thymidylate synthase. J Chemother. 2001; 13:519-526.

2. Correale P, Del Vecchio MT, Di Genova G, Savellini GG, La Placa M, Terrosi C, Vestri M, Urso R, Lemonnier F, Aquino A, Bonmassar E, Giorgi G, Francini G, et al. 5-fluorouracilbased chemotherapy enhances the antitumoractivity of a thymidylatesynthase-directedpolyepitopic peptide vaccine. J Natl Cancer Inst. 2005; 97:1437-1445.

3. Correale P, Del Vecchio MT, La Placa M, Montagnani F, Di Genova G, Savellini GG, Terrosi C, Mannucci S, Giorgi 
G, Francini G, Cusi MG. Chemotherapeutic drugs may be used to enhance the killing efficacy of human tumor antigen peptide specific CTLs. J Immunother. 2008; 31:132-147.

4. Correale P, Cusi MG, Giorgi G, Francine G, inventors; Università Degli Studi Di Siena, assignee. Poly-epitope peptide derived from thymidylate synthase having immunological and anti-tumor activity. World patent WO patent 2006087756A3. 2006 Feb 16.

5. Cusi MG, Botta C, Pastina P, Rossetti MG, Dreassi E, Guidelli GM, Fioravanti A, Martino EC, Martorelli B, Pagliuchi M, Basile M, Carbone SF, Ricci V, et al. Phase I Trial of Thymidylate-synthasepoly-epitope peptide (TSPP) vaccine in advanced cancer patients. Cancer Immunol Immunother. 2015; 64:1159-1173.

6. Correale P, Botta C, Martino EC, Ulivieri C, Battaglia G, Carfagno T, Rossetti MG, Fioravanti A, Guidelli GM, Cheleschi S, Gandolfo C, Carbone F, Baldari TC, et al. Phase Ib study of poly-epitope peptide vaccination to thymidylate synthase (TSPP) and GOLFIG chemoimmunotherapy for treatment of metastatic colorectal cancer patients. Oncoimmunology. 2016; 5:e1101205.

7. Correale P, Campoccia G, Tsang KI, Micheli L, Cusi MG, Sabatino M, Bruni G, Sestini S, Petrioli R, Pozzessere D, Marsili S, Fanetti G, Giorgi G, et al. Recruitment of dendritic cells and enhanced antigen specific immunereactivity in cancer patients treated with hrGM-CSF (molgramostim) and hr IL-2: results from a Phase $\mathrm{Ib}$ Clinical Trial. Eur J Cancer. 2001; 37:892-902.

8. Correale P, Cusi MG, Del Vecchio MT, Aquino A, Prete SP, Tsang KY, Micheli L, Nencini C, La Placa M, Montagnani F, Terrosi C, Caraglia M, Formica V, et al. Dendritic cellmediated cross-presentation of antigens derived from colon carcinoma cells exposed to a highly cytotoxic multidrug regimen with gemcitabine, oxaliplatin, 5-fluorouracil, and leucovorin, elicits a powerful human antigen-specific CTL response with antitumor activity in vitro. J Immunol. 2005; 175:820-828.

9. Correale P, Cusi MG, Tsang KY, Del Vecchio MT, Marsili $\mathrm{S}$, Placa ML, Intrivici C, Aquino A, Micheli L, Nencini C, Ferrari F, Giorgi G, Bonmassar E, et al. Chemoimmunotherapy of metastatic colorectal carcinoma with gemcitabine plus FOLFOX 4 followed by subcutaneous granulocyte macrophage colony-stimulating factor and interleukin-2 induces strong immunologic and antitumor activity in metastatic colon cancer patients. J Clin Oncol. 2005; 23:8950-8958.

10. Correale P, Tagliaferri P, Fioravanti A, Del Vecchio MT, Remondo C, Montagnani F, Rotundo MS, Ginanneschi C, Martellucci I, Francini E, Cusi MG, Tassone P, Francini G. Immunity feedback and clinical outcome in colon cancer patients undergoing chemo-immunotherapy with Gemcitabine + FOLFOX followed by subcutaneous Granulocyte Macrophage-Colony Stimulating Factor and Aldesleukine (GOLFIG-1 trial). Clin Cancer Res. 2008; 14:4192-4199.
11. Correale P, Botta C, Rotundo MS, Guglielmo A, Conca R, Licchetta A, Pastina P, Bestoso E, Ciliberto D, Cusi MG, Fioravanti A, Guidelli GM, Bianco MT, et al. Immuneboost with gemcitabine, oxaliplatin, levofolinate, 5-flurouracil, granulocyte/macrophagecolony-stimulatingfactor (GM-CSF) and aldesleukine (GOLFIG) enhancesprogression-free and overall-survival over FOLFOX chemotherapy in metastaticcolorectalcancerpati ents: GOLFIG-2 multi-centric open labelrandomizedphase III trial. J Immunother. 2014; 37:26-35.

12. Nappi A, Berretta M, Romano C, Tafuto S, Cassata A, Casaretti R, Silvestro L, De Divitiis C, Alessandrini L, Fiorica F, Ottaiano A, Nasti G. Metastatic colorectal cancer: role of target therapies and future perspectives. Curr Cancer Drug Targets. 2017 Feb 8. [Epub ahead of print].

13. Correale P, Botta C, Ciliberto D, Pastina P, Ingargiola R, Zappavigna S, Tassone P, Pirtoli L, Caraglia M, Tagliaferri P. Immunotherapy of colorectal cancer: new perspectives after a long path. Immunotherapy. 2016; 8:1281-1292.

14. Roviello G, Zanotti L, Correale P, Gobbi A, Wigfield S, Guglielmi A, Pacifico C, Generali D. Is still there a role for IL-2 for solid tumors other than melanoma or renal cancer? Immunotherapy. 2017; 9:25-32.

15. Bever KM, Le DT. An Expanding Role for Immunotherapy in Colorectal Cancer. J Natl Compr Canc Netw. 2017; 15:401-410.

16. Naboush A, Roman CA, Shapira I.Immune checkpoint inhibitors in malignancies with mismatch repair deficiency: a review of the state of the current knowledge. J Investig Med. 2017; 65:754-758.

17. Rébé C, Ghiringhelli F. Cytotoxic effects of chemotherapy on cancer and immune cells: how can it be modulated to generate novel therapeutic strategies? Future Oncol. 2015 Sep 17. [Epub ahead of print].

18. Chajon E, Castelli J, Marsiglia H, De Crevoisier R.The synergistic effect of radiotherapy and immunotherapy: A promising but not simple partnership. Crit Rev Oncol Hematol. 2017; 111:124-132.

19. Correale P, Botta C, Cusi MG, Del Vecchio MT, De Santi MM, Gori Savellini G, Bestoso E, Apollinari S, Mannucci S, Marra M, Abbruzzese A, Aquino A, Turriziani M, et al. Cetuximab \pm chemotherapy enhances dendritic cellmediated phagocytosis of colon cancer cells and ignites a highly efficient colon cancer antigen-specific cytotoxic T-cell response in vitro. Int J Cancer. 2012; 130:1577-1589.

20. Botta C, Bestoso E, Apollinari S, Cusi MG, Pastina P, Abbruzzese A, Sperlongano P, Misso G, Caraglia M, Tassone P, Tagliaferri P, Correale P. Immunemodulating effects of the newest cetuximab-based chemoimmunotherapy regimen in advanced colorectal cancer patients. J Immunother. 2012; 35:440-447.

21. Caraglia M, Marra M, Budillon A, Meo G, Ricciardiello F, Bismuto E, Brachelente G, Francini G, Giordano A, Correale P, Abbruzzese A. Chemotherapy regimen GOLF induces apoptosis in colon cancer cells through 
multi-chaperone complex inactivation and increased Raf-1 ubiquitin-dependent degradation.Cancer Biol Ther. 2005; 4:1159-1167.

22. Nardi N, Brito-Zerón P, Ramos-Casals M, Aguiló S, Cervera R, Ingelmo M, Font J. Circulating auto-antibodies against nuclear and non-nuclear antigens in primary Sjögren's syndrome: prevalence and clinical significance in 335 patients. Clin Rheumatol. 2006; 25:341-346.

23. Park HK, Kim SK, Kweon HY, Lee KG, Arasu MV, Kim YO. Promoter polymorphism (-590, T/C) of interleukin 4 (IL4) gene is associated with rheumatoid arthritis: An updated meta-analysis. J Biol Sci. 2017; 24:444-449.

24. Filer AD, Gardner-Medwin JM, Thambyrajah J, Raza K, Carruthers DM, Stevens RJ, Liu L, Lowe SE, Townend JN, Bacon PA. Diffuse endothelial dysfunction is common to ANCA associated systemic vasculitis and polyarteritisnodosa. Ann Rheum Dis. 2003; 62:162-167.

25. Pampena MB, Levy EM. Natural killer cells as helper cells in dendritic cell cancer vaccines. Front Immunol. 2015; 6:13.

26. Kuwabara T, Ishikawa F, Kondo M, Kakiuchi T. The Role of IL-17 and Related Cytokines in Inflammatory Autoimmune Diseases. Mediators Inflamm. 2017; 2017:3908061.

27. Krstic J, Obradovic H, Kukolj T, Mojsilovic S, OkicDordevic I, Bugarski D, Santibanez JF. An Overview of Interleukin-17A and Interleukin-17 Receptor A Structure, Interaction and Signaling. Protein Pept Lett. 2015; 22:570-578.

28. Benchetrit F, Ciree A, Vives V, Warnier G, Gey A, SautesFridman C, Fossiez F, Haicheur N, Fridman WH, Tartour E. Interleukin-17 inhibits tumor cell growth by means of a T-cell-dependent mechanism. Blood. 2002; 99:2114-2121.

29. Mantovani A, Allavena P, Sica A, Balkwill F. Cancer-related inflammation. Nature. 2008; 454:436-444.

30. Grivennikov SI, Greten FR, Karin M. Immunity, inflammation, and cancer. Cell. 2010; 140:883-899.

31. Jafri SH, Shi R, Mills G. Advance lung cancer inflammation index (ALI) at diagnosis is a prognostic marker in patients with metastatic non-small cell lung cancer (NSCLC): a retrospective review. BMC Cancer. 2013; 13:158.

32. Botta C, Barbieri V, Ciliberto D, Rossi A, Rocco D, Addeo R, Staropoli N, Pastina P, Marvaso G, Martellucci I, Guglielmo A, Pirtoli L, Sperlongano P, et al. Systemic inflammatory status at baseline predicts bevacizumab benefit in advanced non-small celllungcancerpatients. Cancer Biol Ther. 2013; 14:469-475.

33. Templeton AJ, McNamara MG, Seruga B, Vera-Badillo FE, Aneja P, Ocana A, Leibowitz-Amit R, Sonpavde G, Knox JJ, Tran B, Tannock IF, Amir E. Prognostic role of neutrophilto-lymphocyte ratio in solidtumors: a systematicreview and meta-analysis. J Natl Cancer Inst. 2014; 106:dju124.
34. Predina J, Eruslanov E, Judy B, Kapoor V, Cheng G, Wang LC, Sun J, Moon EK, Fridlender ZG, Albelda S, Singhal S. Changes in the local tumor microenvironment in recurrent cancers may explain the failure of vaccines after surgery. Proc Natl Acad Sci U S A. 2013; 110:E415-424.

35. Cedrés S, Torrejon D, Martínez A, Martinez P, Navarro A, Zamora E, Mulet-Margalef N, Felip E. Neutrophil to lymphocyte ratio (NLR) as an indicator of poor prognosis in stage IV non-small cell lung cancer. Clin Transl Oncol. 2012; 14:864-869.

36. Botta C, Misso G, Martino EC, Pirtoli L, Cusi MG, Tassone P, Tagliaferri P, Caraglia M, Correale P. The route to solve the interplay between inflammation, angiogenesis and anti-cancer immune response. Cell Death Dis. 2016; 7:e2299.

37. Haghshenas MR, Khademi B, Faghih Z, Ghaderi A, Erfani N. Immune regulatory cells and IL17-producing lymphocytes in patients with benign and malignant salivary gland tumors. Immunol Lett. 2015; 164:109-116.

38. Aghaeepour N, Chattopadhyay P, Chikina M, Dhaene T, Van Gassen S, Kursa M, Lambrecht BN, Malek M, McLachlan GJ, Qian Y, Qiu P, Saeys Y, Stanton R, et al. A benchmark for evaluation of algorithms for identification of cellular correlates of clinical outcomes. Cytometry A. 2016; 89:16-21.

39. Ku JH, Kang M, Kim HS, Jeong CW, Kwak C, Kim HH. The prognostic value of pretreatment of systemic inflammatory responses in patients with urothelial carcinoma undergoing radical cystectomy. Br J Cancer. 2015; 112:461-467.

40. Kimura H, Caturegli P, Takahashi M, Suzuki K. New Insights into the Function of the Immunoproteasome in Immune and Nonimmune Cells. J Immunol Res. 2015; 2015:541984.

41. Sfanos KS, Hempel HA, De Marzo AM. The role of inflammation in prostate cancer. Adv Exp Med Biol. 2014; 816:153-181.

42. Zelba H, Weide B, Martens A, Derhovanessian E, Bailur JK, Kyzirakos C, Pflugfelder A, Eigentler TK, Di Giacomo AM, Maio M, Aarntzen EH, de Vries J, Sucker A, et al. Circulating CD4+ T cells that produce IL4 or IL17 when stimulated by melan-A but not by NY-ESO-1 have negative impacts on survival of patients with stage IV melanoma. Clin Cancer Res. 2014; 20:4390-4399.

43. Gandhi AK, Shi T, Li M, Jungnelius U, Romano A, Tabernero J, Siena S, Schafer PH, Chopra R. Immunomodulatory effects in a phase II study of lenalidomide combined with cetuximab in refractory KRAS-mutant metastatic colorectal cancer patients. PLoS One. 2013; 8:e80437. 